$12-2012$

\title{
Perfecting Criminal Markets
}

David Jaros

University of Baltimore School of Law, djaros@ubalt.edu

Follow this and additional works at: http://scholarworks.law.ubalt.edu/all_fac

Part of the Criminal Law Commons, Criminal Procedure Commons, and the Law and Economics Commons

\section{Recommended Citation}

Perfecting Criminal Markets, 112 Colum. L. Rev. 1947 (2012)

This Article is brought to you for free and open access by the Faculty Scholarship at ScholarWorks@University of Baltimore School of Law. It has been accepted for inclusion in All Faculty Scholarship by an authorized administrator of ScholarWorks@University of Baltimore School of Law. For more information, please contact snolan@ubalt.edu. 


\section{COLUMBIA LAW REVIEW}

VOL. 112

DECEMBER 2012

NO. 8

\section{ARTICLES}

\section{PERFECTING CRIMINAL MARKETS}

\section{David Michael Jaros*}

From illicit drugs to human smuggling to prostitution, legislators may actually perfect the very criminal markets they seek to destroy. Criminal laws often create new dangers and new criminal opportunities. Criminalizing drugs creates opportunities to sell fake drugs. Raising penalties for facilitating illegal immigration increases the risk that smugglers will rely on dangerous methods that can injure or kill their human cargo. Banning prostitution increases the underground spread of sexually transmitted disease. Lawmakers traditionally respond to these "second-order" problems with new waves of criminalization that impose additional penalties on fake-drug dealers, dangerous human smugglers, and HIV-positive prostitutes.

But the criminalization of second-order activities also improves the criminal markets that gave them birth. Criminalizing the sale of fake cocaine strengthens the market for genuine drugs. When the law increases penalties for dangerous human smuggling, those contemplating illegal immigration may pay more for assistance across the border. The total quantity of prostitution will rise when the law makes sex for hire safer. In sum, efforts to criminalize and punish second-order crimes may inadvertently bolster the very criminal markets that legislatures originally sought to eradicate.

This Article suggests that the perfection of criminal markets is not just a quirky economic irony. The dynamic relationship between firstand second-order crimes is relevant to the formation of sound criminal justice policy, and it can help explain the rapid expansion of the criminal code. Moreover, acknowledging that criminal laws may facilitate antisocial activity can destigmatize alternative policies that improve public welfare by making illegal activity safer.

* Assistant Professor of Law, University of Baltimore School of Law. I am grateful for the help and insightful comments of Judge Guido Calabresi, Richard Epstein, Peter Reuter, Jim Liebman, Adam Zimmerman, Emily G. Owens, Miriam Baer, Josh Bowers, Bob Lande, Jordan Matsudaira, Will Hubbard, Colin Starger, Erika Wevodau, Bijal Shah, and all the members of the UB Junior Faculty Scholarship Colloquium. I owe a special debt to my wife for her insightful edits and endless patience with this project. 


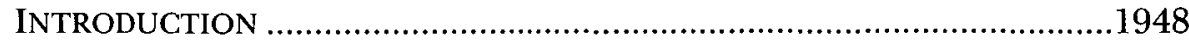

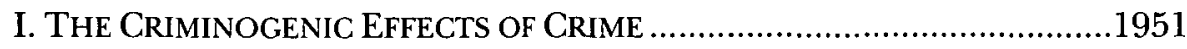

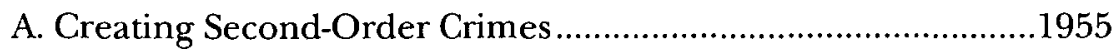

1. Creating Demand for Criminal Markets ...............................1955

2. The Criminogenic Effect of Deregulating Criminal Markets

B. The Independent Costs of Second-Order Crimes .....................1959

II. PERFECTING CRIMINAL MARKETS ....................................................1961

A. How Second-Order Crimes Promote Market Failure, Impose Costs, and Generate Weakness in First-Order Criminal Markets 1962

1. Criminal Exploitation of Asymmetric Information .............1962

2. Second-Order Crimes Can Impose Costs That Weaken First-Order Criminal Markets 1965

3. Second-Order Crimes Can Weaken Competition in First-

Order Criminal Markets .1967

B. How the Criminalization of Second-Order Crimes Perfects First-Order Criminal Markets 1970

III. IMPLICATIONS OF PERFECTING CRIMINAL MARKETS ..........................1975

A. Perfecting Criminal Justice Policy .............................................1976

1. Cost-Benefit Analysis and Criminal Law ............................1977

2. Perfecting the Legislative Process .......................................1978

3. Perfecting the Implementation of Criminal Justice Policy 1980

a. Perfecting Prosecutors.....................................................1981

b. Perfecting Judicial Decisionmaking .............................1982

c. Perfecting the Allocation of Law Enforcement

Resources ................................................................1982

4. Perfecting the Policy Debate ..............................................1985

B. Perfecting Our Understanding of (Over) criminalization..........1985

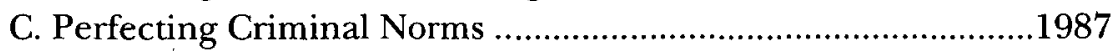

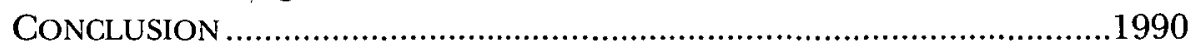

\section{INTRODUCTION}

Can criminal laws improve existing black markets? An unexamined category of laws may actually make black markets more efficient. Laws that criminalize the sale of fake cocaine can improve the market for genuine drugs by reducing the risk that users will buy "bad product." Laws that enhance penalties for alien smugglers who injure or kill their human cargo may increase immigrants' willingness to pay "coyotes" or "snakeheads" to transport them across borders. From prostitution to human smuggling to back-alley abortions, legislators may actually be bolstering the very criminal markets that they seek to destroy. 
That the criminalization of an activity may actually improve related criminal markets has profound implications for criminal justice policy and our normative understanding of criminal law. By recognizing the impact that new criminal laws can have on existing black markets, policymakers can design more effective criminal justice policies and better evaluate the true cost of criminalization. Moreover, recognition that criminal law can facilitate crime may change how society perceives alternatives to criminalization. Critics often disparage harm-reduction strategies such as needle-exchange programs because they theoretically encourage illegal activity. But if criminal laws similarly foster illegal behavior, then neither criminalization nor its alternatives should occupy the moral high ground.

In a basic sense, lawmakers are in the business of creating criminal markets. All forms of regulation have the potential to drive unwanted behavior underground. Criminalizing the sale of illicit drugs creates a black market for drugs. Closing the borders creates a market for human smuggling. But criminal laws create secondary dangers and new criminal opportunities as well. Criminalizing drugs creates the opportunity to sell fake drugs. Raising the penalties for facilitating illegal immigration increases the risk that smugglers will rely on dangerous methods that can injure or kill their human cargo.

Lawmakers respond to these new problems in predictable fashionwith second waves of criminalization and enhanced penalties. More than thirty-five states have made it a crime to sell fake drugs. ${ }^{1}$ Under federal law, if a smuggler causes his human cargo "serious bodily injury," the maximum sentence he faces increases from ten years to twenty. ${ }^{2}$ Should the immigrant die in transit, the smuggler can receive a life sentence or even the death penalty. ${ }^{3}$

What lawmakers fail to recognize is that the criminalization of these "second-order" activities, ${ }^{4}$ while perhaps protecting society from significant harm, also corrects inefficiencies in the criminal markets that gave them birth. By criminalizing and enhancing the penalties for activities like selling fake drugs, dangerous human smuggling, HIV-aware prostitution, dealing drugs while armed, and performing deadly back-alley abortions, lawmakers may strengthen the very criminal markets that they originally sought to eliminate.

1. E.g., Ala. Code $\$ 20-2-143$ (LexisNexis 2006); Cal. Health \& Safety Code $\$ 11355$ (West 2007); Fla. Stat. Ann. § 831.31 (West 2006); Ga. Code Ann. § 16-13-30.2 (2011); Ky. Rev. Stat. Ann. § 218A.140(2) (LexisNexis Supp. 2011); Md. Code Ann., Crim. Law \$ 5-617 (LexisNexis 2012); Mich. Comp. Laws Ann. $\$ 333.7402$ (West Supp. 2012); Mo. Ann. Stat. $\S 195.242$ (West 2011); N.Y. Pub. Health Law $\$ 3383$ (McKinney 2012); 35 Pa. Stat. Ann. $\S 780-113(30)$ (West Supp. 2012).

2. 8 U.S.C. $\S 1324$ (a) (1) (B) (iii) (2006).

3. Id. $\S 1324(\mathrm{a})(1)(\mathrm{B})$ (iv).

4. This Article uses "second-order" to distinguish the new antisocial opportunity that results from the criminalization of a primary or "first-order" activity. 
One of the great benefits of applying economic theory to the study of law is its capacity to identify unexamined assumptions and open uncultivated subjects to further inquiry. An examination of the impact of second-order crimes on first-order criminal markets raises basic questions about the practical and normative implications of using the criminal law to fight antisocial behavior.

Drawing on economic theory, cognitive psychology, and game theory, this Article examines the complicated dynamic between related criminal markets. Many scholars and policymakers have presumed that criminal laws deter bad behavior by increasing the cost of engaging in antisocial activity. ${ }^{5}$ This view has led policymakers to avoid alternative forms of regulation for fear that they would encourage undesirable activities. By taking this theory of deterrence on its own terms and provisionally accepting its assumption that potential criminals are "rational, econometrically grounded actors who weigh the qualities and probabilities of punishment before acting," 6 this Article demonstrates that criminal laws can encourage unwanted behavior in much the same way. As a result, policymakers need to account for the impact that criminalization has upon related criminal markets when they consider new criminal laws.

This Article proceeds in three Parts. Part I explores how criminal laws create new opportunities to engage in antisocial behavior. While numerous scholars have explored the degree to which the criminal justice system increases individuals' propensity to commit crimes, ${ }^{7}$ few legal scholars have examined the role that the criminal law plays in creating new criminal markets. This occurs in two distinct ways. First, criminal laws can create demand for new types of harmful goods and services that are subsequently criminalized. Second, criminalization can create new criminal opportunities by pushing markets underground where the government is unable to use regulatory tools that might prevent the new antisocial activity.

Part II examines how lawmakers inadvertently improve criminal markets when they seek to deter harmful second-order activities. While

5. See Gary S. Becker, Crime and Punishment: An Economic Approach, 76 J. Pol. Econ. 169, 176 (1968) ("[W] hen other variables are held constant, an increase in a person's probability of conviction or punishment if convicted will generally decrease . . the number of offenses he commits."); see also Richard A. Posner, Economic Analysis of Law $\$$ 7.2, at 278 (8th ed. 2011) [hereinafter Posner, Economic Analysis of Law] ("A person commits a crime because the expected benefits exceed the expected costs."). As used in this Article, "antisocial" activities are those in which the net social benefit is negative; that is, the total costs associated with the activity outweigh the benefits.

6. Jeffrey Fagan \& Tracey L. Meares, Punishment, Deterrence and Social Control: The Paradox of Punishment in Minority Communities, 6 Ohio St. J. Crim. L. 173, 181 (2008).

7. See, e.g., id. at 203-04 (suggesting that more punitive criminal justice policies may actually raise crime rate by undermining social controls and reducing stigma associated with illegal behavior); see also Martin H. Pritikin, Is Prison Increasing Crime?, 2008 Wis. L. Rev. 1049, 1054-74 (cataloging crime-causing effects of incarceration). 
imposing considerable costs on society generally, second-order criminal conduct can create inefficiencies in related, first-order criminal markets by generating asymmetries of information, diminishing competition, and increasing the cost of illegal activity. By deterring second-order crimes, policymakers inadvertently strengthen the very criminal markets that they originally sought to eradicate.

Part III describes some broad implications of perfecting criminal markets. The dynamic relationship between first- and second-order crimes is not only relevant to the formation of sound criminal justice policy, it can also help explain the rapid expansion of criminal codes that has been the subject of considerable consternation and academic debate. ${ }^{8}$ Moreover, the recognition that criminal laws actually improve black markets may change how we think about criminalization in relation to other policy options. Focusing attention on the ways in which criminal laws facilitate crime may help to destigmatize alternative harm-reduction policies that improve public welfare by reducing the social costs of illegal activity.

\section{THE CRIMINOGENIC EFFECTS OF CRIME}

You murder me now and steal my throne-but one of your own sons will dethrone you, for crime begets crime. ${ }^{9}$

One of the core goals of the criminal law is to deter antisocial behavior. ${ }^{10}$ On its face, deterrence appears straightforward. In his seminal article applying economic theory to the analysis of criminal law, Gary Becker posited that criminals, like any other rational actors, weigh the expected benefits of their actions against the expected costs. ${ }^{11}$ The criminal law

8. See William J. Stuntz, The Pathological Politics of Criminal Law, 100 Mich. L. Rev. $505,509,513-14$ (2001) (noting dramatic broadening of criminal code over past century and a half); see also Sara Sun Beale, What's Law Got To Do with It? The Political, Social, Psychological and Other Non-Legal Factors Influencing the Development of (Federal) Criminal Law, 1 Buff. Crim. L. Rev. 23, 23-24 (1997) [hereinafter Beale, Non-Legal Factors] (discussing sentencing policy developments including "more mandatory minimums, three strikes provisions, and extending the death penalty").

9. Bernard Evslin, Heroes, Gods and Monsters of the Greek Myths 11 (1967) (recounting Uranus's admonition to his son Cronos, who would later be overthrown by his own son, Zeus).

10. See Harmelin v. Michigan, 501 U.S. 957, 1008 (1991) (Kennedy, J., concurring) (describing deterrence as "one of the first purposes of criminal law"); Warren v. U.S. Parole Comm'n, 659 F.2d 183, 188 (D.C. Cir. 1981) ("[T] he core purpose of the criminal law[] [is] to regulate behavior by threatening unpleasant consequences should an individual commit a harmful act."). This is not to suggest that deterrence is the only possible justification for criminal law. Other classic justifications for criminal law include retribution, incapacitation, and rehabilitation. See Harmelin, 501 U.S. at 999 (Kennedy, J., concurring) ("The federal and state criminal systems have accorded different weights at different times to [these] penological goals ....").

11. Becker, supra note 5, at 176; see also Miriam Hechler Baer, Cooperation's Cost, 88 Wash. U. L. Rev. 903, 918 (2011) ("Under Gary Becker's famous formulation, the ra- 
thus aims to deter crime by raising the cost of certain antisocial activities, thereby diverting rational criminals from the undesirable activity to other, legal and less harmful, pursuits. In practice, however, the use of the criminal law to deter antisocial behavior is fraught with difficulty. In fact, there are times when the criminal law is, itself, criminogenic.

Crime is capable of begetting more crime in a number of subtle ways. Former Acting Solicitor General Neal Katyal has observed that the criminalization and harsh penalization of one antisocial activity may encourage offenders to switch to other endeavors that may be equally or even more harmful. ${ }^{12}$ Thus, when Congress raised the penalty for possessing five grams of crack to a mandatory minimum of five years, it inadvertently may have induced dealers to substitute the sale of heroin for the sale of crack. ${ }^{13}$ Professor Katyal further hypothesized that the increased criminalization of certain kinds of illegal activity (like heroin use for addicts) could actually increase the incidence of those activities. Likening heroin to a Giffen good-a good which people consume more of as its price rises ${ }^{14}$ - Professor Katyal suggested that increased prices for heroin could actually induce users to consume more drugs to cope with the misery of lost income. ${ }^{15}$

Crime also begets incarceration; incarceration, in turn, can beget more crime ${ }^{16}$ Prisons act as schools for inexperienced criminals, inculcating low-level offenders with criminal values as well as educating them

tional actor refrains from wrongdoing when the expected costs of such conduct outweigh its expected benefits.").

12. See Neal Kumar Katyal, Deterrence's Difficulty, 95 Mich. L. Rev. 2385, 2402-08 (1997) (using sale of crack cocaine and heroin to describe substitution effects in criminal law).

13. Id. at 2402-03. Neither Professor Katyal nor this Article makes any empirical claim as to the relative harm of selling crack as opposed to heroin. The point is simply that the criminalization and penalization of one activity may lead to the substitution of other criminal activities.

14. The term "Giffen good" comes from the nineteenth-century economist Sir Robert Giffen, who is popularly thought to have observed that Irish families paradoxically increased their consumption of potatoes during the Irish potato famine, despite a dramatic rise in the price of potatoes. Giffen surmised that the rise in potato prices left families substantially poorer, so that they could no longer afford to substitute meat for potatoes. As a result, families ate more potatoes than they had in the past, despite the fact that meat had become relatively cheaper. Terrence McDonough \& Joseph Eisenhauer, Sir Robert Giffen and the Great Potato Famine: A Discussion of the Role of a Legend in Neoclassical Economics, 29 J. Econ. Issues 747, 747-48 (1995).

15. Katyal, supra note 12 , at 2436 .

16. Jeffrey Fagan, Valerie West \& Jan Holland, Reciprocal Effects of Crime and Incarceration in New York City Neighborhoods, 30 Fordham Urb. L.J. 1551, 1554 (2003); see also David E. Patton, Guns, Crime Control, and a Systemic Approach to Federal Sentencing, 32 Cardozo L. Rev. 1427, 1436 (2011) (“[I]mprisonment itself has criminogenic effects."); Pritikin, supra note 7, at 1102-03 ("[C]onsidering the full panoply of prison's criminogenic effects, our system of incarceration may not even be yielding a nationwide net benefit in terms of simple crime prevention itself."). 
on the means to commit more serious crimes. ${ }^{17}$ By separating prisoners from their families, incarceration can also weaken the social ties that act as "informal social control[s]" to deter criminal activity. ${ }^{18}$ Moreover, a criminal record can make it substantially harder for an individual to obtain legal employment, thereby increasing the chances that a convicted person will have to rely on crime for income in the future. ${ }^{19}$ This dynamic is exacerbated by the fact that incarceration tends to strengthen a convicted person's connection to criminal networks, thereby expanding the person's opportunities to engage in further criminal activity. ${ }^{20}$

Incarceration (and thus criminal law) can result in the increased criminal activity of third parties as well. As Martin Pritikin observes, " $[\mathrm{n}]$ ot only does the disruption of family bonds that results from incarceration make those in prison more likely to recidivate, it makes their children more likely to commit crime as well." ${ }^{21}$ Without the supervision of their parents, the children of incarcerated persons have increased opportunities to become involved in delinquency and crime. ${ }^{22}$ Moreover, the deleterious economic impact of a parent's incarceration may increase the likelihood that a child will pursue the financial benefits of criminal activity. ${ }^{23}$ Indeed, incarceration can have a broad criminogenic effect on entire communities as high rates of imprisonment exacerbate the social and economic disadvantages that plague impoverished communities

17. Pritikin, supra note 7, at 1054-55; see also Katyal, supra note 12, at 2398 n.32 ("[W]e must add to th [e] cost[s] of punishment the fact that imprisonment often breeds crime because of the unsavory contacts one meets while imprisoned, contacts that may reduce the cost of further criminal activity.").

18. Fagan \& Meares, supra note 6, at 196-202 (describing how weakened family and community structures undermine informal social control); see also Pritikin, supra note 7 , at 1055 ("It may be not merely the strengthening of deviant bonds within prison that leads to increased criminality, but also the weakening of social bonds with family and community on the outside.").

19. See Fagan \& Meares, supra note 6, at 203 ("The assignment of a criminal record places concrete and lasting barriers to future employment, and for former inmates, reduces their choices with respect to avoiding crime and entering positive social roles."); James Jacobs \& Tamara Crepet, The Expanding Scope, Use, and Availability of Criminal Records, 11 N.Y.U. J. Legis. \& Pub. Pol'y 177, 178-79 (2008) ("Persons stigmatized with a criminal label face de jure and de facto discrimination in employment, housing, and access to government social welfare benefits."); Devah Pager, The Mark of a Criminal Record, 108 Am. J. Soc. 937, 961 (2003) ("The fact that a criminal record severely limits employment opportunities . . . suggests that these individuals are left with few viable alternatives [to crime]."); Pritikin, supra note 7, at 1061-63 (identifying various ways in which incarceration can reduce employment opportunities).

20. Fagan \& Meares, supra note 6, at 209 (citing Jeremy Travis, But They All Come Back: Facing the Challenges of Prisoner Reentry 166 (2005)).

21. Pritikin, supra note 7 , at 1066-67.

22. Fagan \& Meares, supra note 6 , at 205 (citing Robert J. Sampson \& John H. Laub, Urban Poverty and the Family Context of Delinquency: A New Look at Structure and Process in a Classic Study, 65 Child Dev. 523, 531-33, 538-39 (1994)).

23. Pritikin, supra note 7 , at 1065-66. 
where former inmates are concentrated. ${ }^{24}$ Thus, incarceration is not merely a consequence of neighborhood crime, but also a critical piece of the "ecological dynamics of neighborhoods that may actually elevate crime." ${ }^{25}$

Yet despite the rich scholarly literature on the sociological, psychological, and economic impacts of criminalization and incarceration and their criminogenic effects, one important dynamic has been overlooked. Scholars have observed that efforts to restrict the supply of illegal goods (like drugs) tend to raise the price of those goods. As prices rise, criminals have greater incentive to engage in the illegal activity and to utilize violence to maintain their market position..$^{26}$ Criminalization, however, does more than simply create imperfect markets that reward illegal behavior. Sometimes criminalization creates second-order criminal markets-new criminal opportunities that would not exist but for the criminalization of the initial antisocial activity.

This dynamic is critically important. First, it suggests the possibility that legislators and law enforcement grossly underestimate the social costs of criminalizing some activities. Second, and more importantly, close examination of the relationship between first- and second-order criminal markets suggests that lawmakers and law enforcement officials must be cautious in their responses to second-order crimes. Otherwise, in their effort to combat the second-order crime, policymakers may unwittingly improve the market for the original crime, thereby raising law enforcement costs and increasing the level of the very activity they initially sought to suppress.

This Part proceeds as follows. Part I.A describes two ways in which first-order crimes generate new criminal activities. First, the criminalization of a good or activity can create demand for new harmful goods and services. ${ }^{27}$ Second, the criminalization of a good or activity creates new

24. See Fagan \& Meares, supra note 6, at 205-06 (discussing how "high incarceration levels affect the ... economic circumstances of African-American communities"); Fagan et al., supra note 16, at 1552-53 (describing how high rates of incarceration can undermine local social and economic stability, thereby contributing to rise in crime).

25. Fagan et al., supra note 16 , at 1553.

26. See Stephen J. Schulhofer, Solving the Drug Enforcement Dilemma: Lessons from Economics, 1994 U. Chi. Legal F. 207, 223-24 (contending that drug dealers' incentive to use violence increases with drug prices); Charles $\mathbf{H}$. Whitebread, Freeing Ourselves from the Prohibition Idea in the Twenty-First Century, 33 Suffolk U. L. Rev. 235, 252 (2000) ("Indeed, enforcement may increase the profits for many of these drug traffickers and may, as it often does, operate to increase the levels of violence."). The increase in the price of drugs resulting from criminalization may also lead to an increase in property crimes as drug users seek to fund their addiction through more crime. See Shawn Bushway \& Peter Reuter, Economists' Contribution to the Study of Crime and the Criminal Justice System, 37 Crime \& Just. 389, 425 (2008) (noting dependent users commit crimes to fund drug purchases).

27. As discussed below, this increased demand for secondary antisocial goods and services is distinct from the increased demand for substitute criminal goods and services that 
opportunities for harmful behavior by foreclosing the government from using regulatory tools that might prevent the new activity from occurring. Part I.B then describes how the new activities generated by first-order criminalization impose independent costs on society that tend to trigger a second wave of criminalization.

\section{A. Creating Second-Order Crimes}

Second-order crimes are the product of two unfortunate consequences of criminalizing first-order antisocial conduct. First, the criminalization of a first-order activity can create demand for new types of goods and services that impose their own costs on society. For example, by criminalizing unauthorized entry across U.S. borders, Congress created demand for human smuggling services. Second, criminalization can create the opportunity for second-order crimes by pushing the undesirable activity underground, where the government is unable to use regulatory tools that might prevent the crime from occurring. The combination of these two effects serves to multiply the growth of the criminal law as the symptoms of criminalization lead to more criminalization-expanding criminal codes, contributing to the complexity of sentencing guidelines, and, perversely, adding to the enforcement costs associated with preventing the initial first-order crime.

1. Creating Demand for Criminal Markets. - It is not easy to eliminate crime. The threat of criminal penalties will be sufficient to deflect some people toward legal options. Others will be deterred, not by the fear of criminal sanctions, but because they simply do not want to break the law. In this respect, the criminal law does not simply increase the cost of consumption; it shapes consumer preferences and effectively devalues the criminalized conduct. ${ }^{28}$ However, while criminalization will tend to reduce the prevalence of an undesirable activity, ${ }^{29}$ it will rarely be sufficient to eradicate that activity entirely. ${ }^{30}$ In fact, while criminalization may deter some consumers from participating in a socially undesirable activity, it

results when criminals shift their criminal behavior in response to changes in the relative cost of pursuing a particular kind of criminal activity. See infra Part I.A.1. For an in-depth discussion of the "substitution effect" and crime, see generally Katyal, supra note 12.

28. See Kenneth G. Dau-Schmidt, An Economic Analysis of the Criminal Law as a Preference-Shaping Policy, 1990 Duke L.J. 1, 2 (“[I]n addition to creating disincentives for criminal activity, criminal punishment is intended to promote various social norms of individual behavior by shaping the preferences of criminals and the population at large.").

29. But see Katyal, supra note 12, at 2435 (proposing circumstances in which criminalization or increased penalties may actually increase incidence of illegal activity).

30. In fact, given the exorbitant enforcement costs associated with erasing the last vestiges of crime, in most cases the complete elimination of the activity will be economically inefficient even if we assume it is practically possible. See Becker, supra note 5, at 170 (suggesting optimal level of deterrence would "permit" certain number of offenses and leave certain number of offenders unpunished). 
can also generate demand for goods and services that lead to the formation of new criminal markets.

Criminalization increases the price of an illegal good in two ways. First, it adds the expected cost of punishment to the price of the criminalized good. For example, assume the penalty for possession of a small quantity of marijuana were a $\$ 100$ fine and there were a five percent chance of detection. If it cost $\$ 10$ to purchase a bag of marijuana, then criminalization would raise the total expected cost of consumption to $\$ 15 .^{31}$ Criminalization also raises the price of illegal consumption by eliminating legal avenues to obtain the good. Consumers must expend additional resources to find and safely access criminal markets. For example, criminalizing unauthorized entry into the United States made it more difficult for undocumented individuals to cross the border. While it is relatively inexpensive for individuals to drive through legal checkpoints, it is far more expensive to avoid the authorities and enter via remote routes that are physically dangerous and require considerably more planning and supplies.

A rise in the price of an illegal good resulting from criminalization is generally considered a good thing - this is how the criminal law is typically understood to deter antisocial behavior. ${ }^{32}$ However, the rise in prices and the elimination of legal avenues of access also creates the opportunity for entrepreneurs to offer services or goods that facilitate the cheap and successful completion of the crime. These might be services which lower the risk of detection (like radar detectors) or services that directly facilitate the commission of the crime (like human smuggling). The secondary market may not always impose new social costs. The imposition of a speed limit gave rise to a rich market in radar detection technology. However, while radar detectors may hamper the effort to lower the social costs of speeding, radar detectors do not impose their own independent costs on society. ${ }^{33}$ Unfortunately, this is not true for every secondary criminal market. In many instances, the new activity carries its own social costs, separate and apart from its effect on the firstorder criminal market. As discussed below, the smuggling of illegal aliens not only frustrates government efforts to keep the border closed, it can also increase the risk that would-be immigrants will die. ${ }^{34}$ The political

31. $\$ 10+(\$ 100)(.05)=\$ 15$. This calculation, of course, assumes for simplicity's sake that there are no costs associated with marijuana possession other than the actual fine of $\$ 100$.

32. See Becker, supra note 5 , at 176 (discussing relationship between cost and benefit of crime and its rate of incidence). But see Dau-Schmidt, supra note 28, at 2 (suggesting criminal law deters by shaping preferences).

33. See Nikolaus F. Schandlbauer, Comment, Busting the "Fuzzbuster": Rethinking Bans on Radar Detectors, 94 Dick. L. Rev. 783, 797 (1990) (discussing national study concluding radar detectors do not diminish highway safety).

34. See infra text accompanying notes 94-95 (discussing costs imposed on first-order criminal market by second-order crime of smuggling undocumented immigrants). 
response to such independent costs is often to criminalize the secondary activity. ${ }^{35}$ It is this second wave of criminalization that can perversely improve the market for a crime the legislature originally tried to prohibit.

Creating demand for secondary goods and services is not the only way that criminalization generates new criminal markets. Criminalization can also engender second-order crimes by eliminating barriers that prevent secondary criminal markets from forming in the first place.

2. The Criminogenic Effect of Deregulating Criminal Markets. - Criminalization is often described as a form of regulation. ${ }^{36}$ In some cases, criminal and civil penalties work side by side, overlapping and complementing each other's efforts. Securities markets are governed not only by civil regulations but by the criminal law as well. When Bernie Madoff committed the largest fraud in U.S. history, he violated both civil and criminal statutes. ${ }^{37}$ However, the opposite may also be true-often the criminal law deregulates by pushing markets underground, beyond the reach of traditional civil regulatory tools. ${ }^{38}$ In many respects, criminalization represents a policy choice to eschew other methods of controlling antisocial behavior ${ }^{39}$ By eliminating other regulatory options, criminalization can create the space for the development of secondary criminal marketsmarkets that might have difficulty forming in actively regulated industries. $^{40}$

35. See infra notes 112-115 and accompanying text (discussing widespread criminalization of HIV-aware prostitution as example of second-order criminalization).

36. E.g., Nicola Lacey, Criminalization as Regulation: The Role of Criminal Law, in Regulating Law 144 (Christine Parker et al. eds., 2004); see also Peter Reuter, The Organization of Illegal Markets: An Economic Analysis 17 (1985) [hereinafter Reuter, Illegal Markets] ("All illegal businesses, like most legal business in contemporary America, are subject to regulation by government authority. For illegal businesses, the regulators are the police."); Adam S. Zimmerman \& David M. Jaros, The Criminal Class Action, 159 U. Pa. L. Rev. 1385, 1406-10 (2011) (describing prosecutors as regulators).

37. See Diana B. Henriques, Madoff, Apologizing, Is Given 150 Years, N.Y. Times, June 30, 2009, at Al (noting criminal penalties in Madoff trial and simultaneous civil enforcement).

38. See, e.g., Amanda Dumey, Comment, The Sex Worker's Dilemma: Keeping Cambodia's Sex Trafficking Law from Negating the Successes of the $100 \%$ Condom Use Program, 16 Tulsa J. Comp. \& Int'l L. 215, 241 (2009) ("By criminalizing solicitation of prostitution, the Cambodian government has essentially deregulated the industry.").

39. See infra Part III (comparing criminalization with regulatory approaches to antisocial behavior). The difficulty of regulating criminalized markets is amplified by concerns that the regulation of antisocial behavior will be perceived as tacit social acceptance of that activity. See infra Part III.C (discussing relationship of criminalization to social norms).

40. This is not to suggest that active regulation will always prevent criminal markets from forming. The regulation of the pharmaceutical industry has not entirely eliminated the problem of fake prescription drugs. See, e.g., Counterfeit Version of Avastin in U.S. Distribution, U.S. Food \& Drug Admin. (Feb. 14, 2012), http://www.fda.gov/Drugs/ DrugSafety/ucm291960.htm (on file with the Columbia Law Review) (last updated July 10 , 2012) (warning of illegal sales of counterfeit pharmaceutical drug). In fact, the penalty enhancement for causing serious bodily harm or death in the trafficking of counterfeit goods is another example of a crime that resolves a source of inefficiency in a related crim- 
Take the sale of fake illegal drugs. While the legal pharmaceutical market is subject to strict licensing, labeling, and inspection requirements, the illegal drug market is unfettered by such restrictions. Drug dealers, unlike legitimate pharmaceutical manufacturers, are not subject to surprise visits by FDA inspectors. Similarly, the tiny plastic glassine bags that typify drug packaging on the street ${ }^{41}$ are not labeled with the drugs' active ingredients. Criminalizing and thus deregulating the drug trade makes it far easier for dealers to sell fake drugs to unsuspecting customers. ${ }^{42}$ The criminalization of real drugs thus gives rise to a new criminal opportunity and a secondary market-the sale of fake illegal drugs. ${ }^{43}$

Unlike the secondary markets that develop in response to the demand created by criminalization, markets that form in response to criminal deregulation do not necessarily increase the incidence of the firstorder crime. While radar detectors lead to more speeding and human smuggling ${ }^{44}$ leads to an increase in illegal immigration, sales of fake cocaine, made possible by the deregulatory effect of criminalizing drugs, do not increase the number of real cocaine sales. However, regardless of their origin, many second-order crimes impose costs on society that are wholly independent of their impact on the incidence of the original

inal market. See infra notes 109-111 and accompanying text (describing effect of criminalization of sales of counterfeit drugs).

41. See Jennifer Slosar, Committee Okays Ban on Tiny Plastic Bags, Chi-Town Daily News (Mar. 5, 2008, 8:03 AM), http://www.chitowndailynews.org/Chicago_news/ Committee_okays_ban_on_tiny_plastic_bags, 12559 (on file with the Columbia Law Review) (describing Chicago ordinance banning sale of plastic baggies that typify small-scale drug transactions).

42. The sale of fake drugs does not appear to be limited to the occasional street corner transaction. In February 2011, a large-scale drug ring attempted to sell a New York City gang $\$ 16,000$ of fake cocaine made up of baking soda and crushed sheetrock. Selim Algar, It's Off the "Wall": Sheetrock Cocaine, N.Y. Post, Feb. 4, 2011, at 22. In 2008, a multiagency "East End Drug Task Force" on Long Island recovered two kilograms of fake cocaine along with an Uzi submachine gun. Luis Perez, Cops Bust Two Separate Cocaine Rings, Newsday (Long Island, N.Y.), July 30, 2008, at A25.

43. See David Simon \& Edward Burns, The Corner: A Year in the Life of an InnerCity Neighborhood 69 (1997) (describing "true hucksters" who "sell steakless sizzle" by selling users adulterated heroin cut with lactose and quinine or outright defrauding them by substituting baking soda for heroin, oregano for marijuana, and even battery acid for crack cocaine); see also P. Reuter \& J.P. Caulkins, Illegal "Lemons": Price Dispersion in Cocaine and Heroin Markets, 56 Bull. on Narcotics 141, 160 (2004) [hereinafter Reuter \& Caulkins, Illegal Lemons] (noting that some drug sellers may "specialize in fraud").

44. Here, human smuggling refers to individuals who facilitate illegal entry into the United States. They are often referred to as "snakeheads" or "coyotes," depending on the country of origin. Ian Peck, Note, Removing the Venom from the Snakehead: Japan's Newest Attempt To Control Chinese Human Smuggling, 31 Vand. J. Transnat'l L. 1041, 1043 (1998). This type of human smuggling should be distinguished from that of human traffickers who deal in the market for human slavery. See Developments in the Law-Jobs and Borders, 118 Harv. L. Rev. 2171, 2184 (2005) (quoting U.N. definition of human trafficking). 
crime. It is often these independent costs that induce legislators to engage in a second round of criminalization.

\section{B. The Independent Costs of Second-Order Crimes}

Consider again the fake illegal drug market. A drug user who purchases fake drugs cannot go to the authorities for legal redress. ${ }^{45}$ Without legal recourse, such buyers are apt to resort to self-help measures that can involve violent, even deadly, assault. ${ }^{46}$ While the prospect of violent retribution may deter many drug sellers from offering fake products, other sellers accept this risk. ${ }^{47}$ The violent self-help response that follows the sale of fake illegal drugs imposes its own costs on society, independent of the market for real drugs. Some might question whether society should care about violence inflicted upon a dealer of "fake drugs." Put another way, some would debate whether a proper measure of social utility should include the utility lost by a criminal harmed in retribution for his shady dealings. ${ }^{48}$ However, given the impact of neighborhood violence on third parties-including the danger of innocent-bystander injuries, increased fear in the community, and other "broken windows effects" ${ }^{\prime 9}$ - one need not be concerned with the costs imposed on the criminals themselves to conclude that fake illegal drug sales impose costs on society as a whole.

Like the market for fake drugs, the human smuggling market entails costs that are independent from its impact on the number of immigrants who illegally cross the border. In an effort to avoid detection and maximize profits, smugglers ship their human cargo in squalid conditions that can be hazardous and even deadly. In May 2003, nineteen illegal immi-

45. See Bob Ross, Drug Suspect Really Selling Sheetrock, Times-Picayune (New Orleans), May 25, 1989, at B-3 (reporting police officer's view that fake drug sales create danger that sellers will be "hurt or killed by an angry buyer" because " [a]fter all, who is going to call the police and complain that the man they were buying cocaine from didn't sell them the real thing"').

46. Simon \& Burns, supra note 43 , at 69 (describing how sellers of fake drugs face violent retribution from defrauded customers as well as other dealers who sell real drugs); see also Jonathan Eig, Dealing Fake Crack a Risky Business, Times-Picayune (New Orleans), Aug. 27, 1989, at A-1 (attributing rash of drive-by shootings to rise of phony drug sales); 2 Teens Charged in Stabbing Death, Syracuse Post-Standard, July 6, 2008, at B-8 (reporting alleged murder over sale of fake cocaine).

47. While interning for The Defender Service in Seattle in the summer after my second year of law school, I represented just such a dealer. The prosecutor remarked that my client was "lucky to have sold to an undercover officer" rather than a potentially violent user.

48. This is arguably distinct from the question whether or not the positive utility derived by the criminal as a result of his crime should be included in the calculation of the socially optimal level of crime. See Harold Winter, The Economics of Crime: An Introduction to Rational Crime Analysis 4-6 (2008).

49. See generally James Q. Wilson \& George L. Kelling, Broken Windows: The Police and Neighborhood Safety, Atlantic Monthly, Mar. 1982, at 29 (explaining "broken windows" theory of crime). 
grants suffocated to death in the back of a smuggler's truck when the temperature inside his sealed tractor-trailer reached 173 degrees. ${ }^{50}$ In January 2000, fifteen badly dehydrated Chinese immigrants were discovered crammed into a metal freight container in a Seattle port. ${ }^{51}$ Three dead bodies were discovered decomposing in the rear of the container amid the garbage and human waste that had accumulated during their fifteen-day voyage from China.$^{52}$ Officials concluded that the deaths were the result of either exposure to the cold in the unheated container, lack of water, or a combination of the two. ${ }^{53}$ These human tragedies illustrate the considerable cost human smuggling exacts on society, independent of its effect on the number of illegal immigrants who gain access to the United States.

The independent costs associated with second-order crimes like human smuggling or the sale of fake illegal drugs trigger a predictable legislative response-a second wave of criminalization and enhanced penalties. More than thirty-five state legislatures have criminalized the sale of fake illegal drugs. ${ }^{54}$ Similarly, in 1994, Congress passed the Violent Crime Control and Law Enforcement Act, which increased the maximum term of imprisonment for alien smuggling to twenty years if the smuggler either causes a person serious bodily injury or places the life of any person in jeopardy ${ }^{55}$ Under the Act, a smuggler who causes the death of any person is eligible for the death penalty or life imprisonment. ${ }^{56}$

It is hardly surprising that legislatures would respond to the problems produced by criminalization with more criminalization. Scholars have long observed that the criminal law seems to act as a "one-way ratchet ${ }^{157}$ perpetually expanding its scope and enhancing its penalties. ${ }^{58}$ Increased criminalization would appear to be a reasonable response to

50. Susan Carroll, Trucker Gets 34 Years in Trailer Deaths, Hous. Chron., Jan. 25, 2011 , at B2.

51. Sam Howe Verhovek, Deadly Choice of Stowaways: Ship Containers, N.Y. Times, Jan. 12, 2000, at A1; see also Cleo Kung, Comment, Supporting the Snakeheads: Human Smuggling from China and the 1996 Amendment to the U.S. Statutory Definition of "Refugee," 90 J. Crim. L. \& Criminology 1271, 1283 (2000) (discussing same incident).

52. Verhovek, supra note 51.

53. Id.

54. See supra note 1 (collecting state statutes).

55. Pub. L. No. 103-322, § 60024(1)(G), 108 Stat. 1796, 1981-82 (1994) (codified as amended at 8 U.S.C. $\$ 1324(a)(1)(B))$.

56. Id.

57. See, e.g., Erik Luna, The Overcriminalization Phenomenon, 54 Am. U. L. Rev. 703,719 (2005) ("To begin with, the escalation of 'law and order' politics in recent years has created a one-way ratchet in U.S. governance, churning out an ever-increasing number of crimes and severity of punishments."); Stuntz, supra note 8, at 547 ("[L] egislators will tend to see criminal law as a one-way ratchet.").

58. See David Michael Jaros, Unfettered Discretion: Criminal Orders of Protection and Their Impact on Parent Defendants, 85 Ind. L.J. 1445, 1448 (2010) (describing "everexpanding nature of the criminal law"). 
the significant and even tragic independent costs associated with many second-order crimes. If the logic of deterrence was persuasive for the first-order crime, why should it not apply to the second-order crimes as well? Unfortunately, criminalization in these circumstances is a doubleedged sword. While second-order crimes impose costs on society as a whole, they also create imperfections in the first-order criminal market. The result is that legislatures face a difficult paradox. They can combat the second-order harms with a new wave of criminalization, but, in doing so, they risk improving the first-order criminal market that they originally sought to eliminate. In effect, by criminalizing the secondary harm, they help perfect the original criminal market.

\section{Perfecting CRiminal Markets}

To understand how lawmakers inadvertently perfect criminal markets, one must appreciate the ways in which second-order crimes promote first-order market failures. ${ }^{59}$ There is a certain incongruity in describing the failure of a criminal market. In a sense, one might expect a perfectly efficient criminal market to internalize the ill effects of the criminalized good or activity and thus naturally produce zero crime. ${ }^{60}$ However, for purposes of this Article, it is more useful to momentarily set aside the fact that crimes are, on the whole, harmful to society, and instead think of markets for crime as no different from markets for legal goods and services. A perfect market for crime ${ }^{61}$-like a perfect market for toasters, computers, or the imaginary widget-is thus one in which supply meets demand and the marginal cost of producing the good or service is equal to the price charged to the consumer ${ }^{62}$ Critically, while the failure of an ordinary market involves an inefficient use of resources and a net loss to society, a criminal market failure generally leads to an underproduction of crime-a net gain. Thus, while policymakers gener-

59. As economist and Nobel Prize winner Paul Samuelson suggested, market failures simply describe markets that "do not always lead to the most efficient outcome." Paul A. Samuelson \& William D. Nordhaus, Economics 30 (19th ed. 2010). An efficient outcome, in turn, can be defined as the "most effective use of a society's resources in satisfying people's wants and needs." Id. at 4.

60. In fact, even in an idealized (completely efficient) criminal market, the optimal quantity of crime would likely be greater than zero. This is because some crimes, such as stealing a small quantity of food to save a life, or speeding to get a pregnant mother to the hospital on time, will likely be "value maximizing." Posner, Economic Analysis of Law, supra note $5, \S 7.2$, at 280 .

61. See Niva Elkin-Koren \& Eli M. Salzberger, Law and Economics in Cyberspace, 19 Int'l Rev. L. \& Econ. 553, 554 (1999) ("The tools of microeconomic theory-the curves of supply and demand-can be applied to analyze the market of children for adoption, the market of crimes, or the market of laws in general, as they are applied to the market of apples or cars.").

62. This also suggests a perfectly competitive market in which suppliers are price takers. Otherwise, the marginal cost of production would not equal the price for consumers. 
ally seek to minimize market failure in the legal economy, one would expect them to promote failure in criminal markets.

This Part proceeds as follows. Part II.A examines three mechanisms by which second-order crimes can weaken first-order criminal markets. First, second-order crimes can create asymmetries of information that undermine first-order criminal markets. Second, second-order crimes can impose new costs on first-order criminal activity. Finally, secondorder crimes can reduce competition in first-order criminal markets. Part II.B then identifies how efforts to fight second-order antisocial activity through criminalization can strengthen first-order criminal markets.

\section{A. How Second-Order Crimes Promote Market Failure, Impose Costs, and Generate Weakness in First-Order Criminal Markets}

By their nature, second-order crimes are intimately connected to first-order criminal markets. As a result, second-order crimes can exact costs that weaken demand and promote market failure in first-order criminal markets. They do so by creating the very same conditions that lead to weakness or failure in ordinary markets-they eliminate competition, exploit information asymmetries, and introduce new types of risks and costs into the first-order market.

1. Criminal Exploitation of Asymmetric Information. - In his 1970 article, The Market for "Lemons": Quality Uncertainty and the Market Mechanism, George Akerlof demonstrated how asymmetric information can lead to market failure by describing a used automobile market in which buyers cannot distinguish between good cars and "lemons." 63 Akerlof explained that the seller of a used car possesses greater information about the car's quality than potential buyers. ${ }^{64}$ Unable to distinguish between good cars and "lemons," buyers refuse to offer full price for cars that might not be of high quality. Sellers, in turn, refuse to sell good cars for less than their full value, so the only cars offered for sale are likely to be low-value lemons. The result is a downward spiral of lower prices and lower quality, as the asymmetry of information between buyers and sellers causes the "bad cars to drive out the good. ${ }^{n 65}$

When asymmetric information threatens legitimate markets, the government is often willing to intervene to prevent inefficiency or mar-

63. George A. Akerlof, The Market for "Lemons": Quality Uncertainty and the Market Mechanism, 84 Q.J. Econ. 488, 489-90 (1970); see also Bruce Mann \& Thomas J. Holdych, When Lemons Are Better than Lemonade: The Case Against Mandatory Used Car Warranties, 15 Yale L. \& Pol'y Rev. 1, 2 (1996) ("Informational asymmetry arises when one party to a bargain, usually the seller, has more and better information about the condition of a product than does the buyer.").

64. See Akerlof, supra note 63, at 490 (" $[B]$ ad cars sell at the same price as good cars since it is impossible for a buyer to tell the difference between a good and a bar car; only the seller knows.").

65. Id. 
ket failure. Mandatory labeling requirements and government factory inspections build consumers' confidence that they are getting what they believe they have paid for ${ }^{66}$ State consumer protection laws, such as "lemon laws" that govern automobile markets, diminish the risk that buyers will overpay for defective products. ${ }^{67}$ Notably, such regulation serves the interests of both buyers and sellers: Without some intervention to correct the problems created by asymmetric information, the market could fail altogether, to the detriment of all parties. ${ }^{68}$ Indeed, there are occasions when overt government intervention may not even be required. In some circumstances, sellers will be sufficiently motivated to privately initiate measures to counter the ill effects of asymmetric information. For example, even without lemon laws, car dealers may offer warranties to reassure buyers that they are not being swindled. ${ }^{69}$ Yet even private measures, such as a voluntary seller warranty, require the backing of a legal system to be effective. When asymmetries of information cause a failure in a criminal market, they are far more difficult to resolve.

Criminal markets are particularly likely to involve information asymmetry. Government interventions that help ensure quality in markets for legal goods and services, such as labeling requirements and the promise of frequent government inspections, are not available in black markets. Moreover, private enforcement through the legal system is not an option for criminal market participants. ${ }^{70} \mathrm{~A}$ defrauded purchaser of heroin, for example, cannot simply take his dealer to small claims court or report him to the police for fraud..$^{71}$ The characteristics of criminal transactions-primarily the need to avoid detection by law enforcement-also inhibit the flow of information. While purveyors of legal goods and services can use advertising to inform their customers about

66. See Douglas C. Michael, Self-Regulation for Safety and Security: Final Minutes or Finest Hour?, 36 Seton Hall L. Rev. 1075, 1105 (2006) (describing importance of labeling and inspection to maintaining consumer confidence).

67. Patrick J. Glen, Law as Asymmetric Information: Theory, Application, and Results in the Context of Foreign Direct Investment in Real Estate, 8 Berkeley Bus. L.J., no. 1, 2011, at 116, 122 ("These laws do not eliminate the potentialities of asymmetric information, but, rather, provide recourse to a buyer if he happens to buy a 'lemon' rather than a good car.").

68. See Kabir Masson, Note, Paradox of Presumptions: Seller Warranties and Reliance Waivers in Commercial Contracts, 109 Colum. L. Rev. 503, 507 (2009) ("Seller warranties are a common feature of commercial contracts because they are often in the interests of both the buyer and the seller."). But see Mann \& Holdych, supra note 63, at 3 (observing that incomplete information may prevent market forces from generating efficient warranty terms).

69. See Mann \& Holdych, supra note 63 , at 26 (describing how warranties in private marketplaces exist to combat lemons problem).

70. See Bovard v. Am. Horse Enters., Inc., 247 Cal. Rptr. 340, 343 (Ct. App. 1988) ("Whenever a court becomes aware that a contract is illegal, it has a duty to refrain from entertaining an action to enforce the contract.").

71. See supra notes $45-49$ and accompanying text (discussing societal costs of selfhelp redress for fraudulent black market transactions). 
the quality of their offerings, ${ }^{72}$ black market sellers must weigh the economic benefit of advertising against the risk of attracting the attention of law enforcement. Advertising for illegal goods not only raises the risk of detection-in some cases it can be used as evidence of guilt in a subsequent criminal prosecution. ${ }^{73}$

The difficulty of eliminating asymmetries of information in criminal markets does not necessarily mean that criminal markets are prone to fail altogether. While criminal markets have limited legal avenues to correct for asymmetric information, other methods exist to deter individuals from exploiting such imbalances. ${ }^{74}$ For example, the threat of retributive violence may deter some individuals from taking advantage of asymmetric information..$^{75}$ Moreover, while a stranger may take advantage of an ignorant customer, repeat players have less incentive to exploit their informational advantage.$^{76}$ As a result, criminal markets may tend to rely more heavily on repeat relationships that foster trust between market participants. ${ }^{77}$ For this reason, it is possible that one's reputation as an honest businessperson may actually matter more in criminal markets than it does in the legitimate business world. Yet the ability to prevent some criminal exploitation of asymmetric information does not mean that information imbalances are not taxing criminal markets. Quite the opposite: By imposing additional costs on a criminal market, information asymmetries act as a tax on the crime itself.

This tax takes two forms. First, efforts to eliminate information asymmetries-such as doing business only with acquaintances, exacting violent retribution on defrauders, and the like-can be costly. These expenses increase the cost of committing crimes for criminals just as a literal tax would. Second, while strategies that rely on violent retribution, reputation, and doing business with repeat players may reduce the chances that a seller is ripping off his customers, they will not entirely

72. Government intervention in the form of prohibitions against false advertising, such as those embodied in the Lanham Act, see 15 U.S.C. $\$ 1125$ (a) (1) (B) (2006) (providing federal cause of action for false advertising), helps sellers counter problems of asymmetric information by increasing consumer confidence in the truth of their statements.

73. See, e.g., Helms v. State, 38 So. 3d 182, 185 (Fla. Dist. Ct. App. 2010) (permitting admission of sexually suggestive advertisement on Craigslist as evidence of defendant's intent to profit from prostitution).

74. See Reuter \& Caulkins, Illegal Lemons, supra note 43, at 159-61 (discussing illegal drug market as "repeated game" between buyers and sellers).

75. See supra note 26 and accompanying text (discussing role of violence in maintaining market position in illegal markets).

76. See generally Robert Axelrod, The Evolution of Cooperation (rev. ed. 2006) (demonstrating benefits of adopting cooperative strategies in situations involving repeat players as well as long-term costs associated with cheating).

77. See Reuter \& Caulkins, Illegal Lemons, supra note 43 , at 160 ("[O]ddly enough, . . . even among criminals, trust may be the critical factor."); see also Axelrod, supra note 76, at 173-75 (explaining how "cooperation can get started, can thrive ... and can protect itself once established" in reciprocal environments). 
eliminate cheating. In The Corner: A Year in the Life of an Inner-City Neighborhood, David Simon and Edward Burns describe how some drug dealers regularly defraud their customers. ${ }^{78}$ According to Simon and Burns, the dealers "stand where they want, sell what they want, and risk only the rage of their victims, or in a rare instance, the ire of a street dealer whose business or reputation suffers by proximity." ${ }^{\prime 79}$ As a result, buyers must internalize some risk that sellers are taking advantage of them. Buyers in criminal markets cannot entirely avoid the lemon problem. ${ }^{80}$ Faced with the possibility that sellers are taking advantage of them, buyers will lower the price they are willing to pay just as if there were a literal tax placed on their purchase. ${ }^{81}$

Many second-order crimes involve the exploitation of asymmetric information in criminal markets. The sale of fake drugs, for example, takes advantage of the asymmetry of information between sellers (dealers) and buyers (users) ${ }^{82}$ Other second-order crimes may involve less obvious forms of asymmetric information that still produce inefficiencies in the first-order criminal market. A "coyote" or "snakehead"83 who promises a would-be undocumented immigrant a safe voyage may have an incentive to misrepresent how safe his services are as well as the likelihood that their venture will succeed. Snakehead customers, who possess less information than the smugglers themselves, are likely to demand a discount and may even refuse to participate in the market at all rather than accept the risk that the smuggler has misrepresented the quality of his services. Like drug dealers and used car salesmen, human smugglers may find that possessing superior knowledge of their operations and its attendant dangers actually translates into fewer transactions and lower profits.

2. Second-Order Crimes Can Impose Costs That Weaken First-Order Criminal Markets. - Guns are often regarded as "an essential tool of commerce" in illegal markets. ${ }^{84}$ In the absence of legal systems to resolve disputes, guns may be used by market participants to enforce contracts, guarantee physical safety, and ensure the quality of goods and services. ${ }^{85}$ Yet the use of

78. Simon \& Burns, supra note 43 , at 69 .

79. Id.

80. See supra notes $63-65$ and accompanying text (discussing problem of "lemons" caused by asymmetric information in markets).

81. According to Simon and Burns, honest sellers may also have to expend additional resources eliminating dishonest competitors who indirectly damage their reputation. See Simon \& Burns, supra note 43 , at 61 ("What was bad for business was hunted with a vengeance: . . . burn artists were driven deep into the shadows.").

82. See Reuter \& Caulkins, Illegal Lemons, supra note 43 , at 160 (examining variation in drug quality and implications of "lemon effect" in drug markets).

83. See Peck, supra note 44, at 1043 (describing "ominous nicknames" for human smugglers).

84. Lance Lindeen, Keep Off The Grass!: An Alternative Approach to the Gun Control Debate, 85 Ind. L.J. 1659, 1688 (2010).

85. See id. at 1687-88 (discussing how drug prohibition and enforcement lead to increased violence); see also Peter Reuter, Disorganized Crime: The Economics of the Visi- 
gun violence (or the threat of gun violence) in illegal markets as a substitute for legal mechanisms of dispute resolution does not necessarily mean that guns improve the ability of illegal markets to function properly. In fact, gun possession and gun violence, like many secondorder crimes, can impose significant costs on first-order criminal markets. ${ }^{86}$

As an initial matter, it is by no means assured that guns are needed for illegal markets to function. Instead, gun possession may present market participants with a prisoner's dilemma-a situation in which participants would prefer a world where no one carries a gun to a world where everyone carries a gun. ${ }^{87}$ However, because coordination is difficult and each participant cannot afford to be the only one who isn't "packing," all participants may be forced to arm themselves ${ }^{88}$ As a result, the fact that illegal market participants tend to rely heavily on guns does not prove that the existence of guns lowers the cost of conducting illegal business.

Moreover, gun possession almost certainly imposes significant costs on criminal activity. Drug dealers, aware that the presence of guns increases their chance of being injured or killed, have to be compensated for the risks that they take. ${ }^{89}$ This additional compensation is often described as a "risk premium."

ble Hand 132-50 (1983) [hereinafter Reuter, Disorganized Crime] (describing role of violence in illegal markets); Nora V. Demleitner, Organized Crime and Prohibition: What Difference Does Legalization Make?, 15 Whittier L. Rev. 613, 618-19 (1994) ("[T] he use of force and intimidation is an integral part of the supply of illicit goods."); Johan David Michels, Keeping Dealers off the Docket: The Perils of Prosecuting Serious Drug-Related Offences at the International Criminal Court, 21 Fla. J. Int'l L. 449, 453 (2009) (suggesting drug trade is violent because "the ordinary ultimate forum of conflict resolution for regular businesses is unavailable to drug traffickers").

86. Strictly speaking, adding such costs does not mean that the first-order criminal market is inefficient. Indeed, it is often the failure of market participants to properly internalize the true costs (or benefits) of their actions that produces inefficiency. Samuelson \& Nordhaus, supra note 59 , at 36 . Thus, rather than describe the imposition of new costs as causing the first-order criminal market to "fail," it is more accurate to say that the second-order crime "weakens" the first-order market.

87. See Axelrod, supra note 76, at 7-9 (explaining that game theorists use "prisoner's dilemma" to model situations in which "what is best for each person individually leads to mutual defection, whereas everyone would have been better off with mutual cooperation").

88. See generally Robert Taylor, A Game Theoretic Model of Gun Control, 15 Int'l Rev. L. \& Econ. 269 (1995) (applying game theory to behavior of criminals and victims under gun control laws).

89. Some economists estimate that compensation for the risk of physical injury and death accounts for as much as thirty-three percent of the cost of cocaine, while the expense of importing the drug into the country accounts for only twelve percent of its price. Jonathan P. Caulkins \& Peter Reuter, Illicit Drug Markets and Economic Irregularities, 40 Socio-Econ. Plan. Sci. 1, 10 (2006).

90. Juan R. Torruella, The "War on Drugs": One Judge's Attempt at a Rational Discussion, 14 Yale J. on Reg. 235, $263 \mathrm{n} .132$ (1997) (suggesting poor individuals are paid "risk premium" for engaging in drug trade); see also Steven D. Levitt \& Stephen J. 
will shift the supply curve to the left, raising the price of drugs and reducing the total quantity of drug crimes committed. To the extent that buyers are also threatened by the proliferation of guns, ${ }^{91}$ the demand curve will be shifted to the left as well, resulting in a further decrease in drug crimes. ${ }^{92}$ As discussed below, laws that enhance the penalties for possessing a firearm while engaging in drug-related activities may well be justified by society's interest in reducing gun violence. ${ }^{93}$ However, the same enhancements may also lower the costs of engaging in the first-order criminal drug market.

Some second-order crimes, like the smuggling of illegal aliens, ${ }^{94}$ undeniably increase the total quantity of first-order crimes committed. Yet even these second-order crimes can impose costs on the first-order market that complicate criminalization efforts. As described above, there are enormous risks associated with using the services of a human smuggler. When smugglers fail to take sufficient precautions to protect their customers, it is the would-be immigrants who pay the sometimes fatal price. ${ }^{95}$ While tragic, the risks associated with utilizing the services of a human smuggler also have the effect of raising the expected cost of attempting to enter the country illegally (the first-order crime). Thus even those second-order offenses that are essential to the commission of a first-order crime entail costs that have deterrent value. This complex relationship between first- and second-order crimes greatly complicates efforts to regulate antisocial behavior with the criminal law.

3. Second-Order Crimes Can Weaken Competition in First-Order Criminal Markets. - The basic criticism of imperfectly competitive markets is that such markets (usually) fail to allocate resources efficiently by producing less than the optimal amount of a given good. ${ }^{96}$ The result is a net loss to

Dubner, Freakonomics 97 (rev. \& expanded ed. 2006) (describing street dealer's insistence that he receive more money from his boss during period of increased violence due to drug war); Reuter \& Caulkins, Illegal Lemons, supra note 43, at 144 n.* (suggesting high drug prices reflect, in part, substantial risk that seller will be victimized by other market participants).

91. Steven D. Levitt \& Sudhir Alladi Venkatesh, An Economic Analysis of a DrugSelling Gang's Finances, 115 Q.J. Econ. 755, 777 (2000) (“Customers are afraid to come purchase drugs, as evidenced by the following observation by a gang officer: 'Ain't no way nobody gonna come 'round here looking for their rock [crack] if they know they gonna get shot ....'”).

92. In their study of drug finances, Levitt and Venkatesh observed that the average price for drugs fell significantly (even below marginal cost) during periods of escalated violence due to gang warfare over drug territory. Id.

93. See infra text accompanying notes 130-132 (discussing effect of criminalization of second-order gun-related crimes on first-order criminal market).

94. E.g., Ky. Rev. Stat. Ann. $\$ 529.100$ (LexisNexis 2008) (establishing felony liability for "human trafficking").

95. See supra notes 50-53 and accompanying text (describing deadly incidents of human smuggling).

96. Of course, like every statement in economics, the claim that imperfect markets lead to inefficient allocation of resources is based upon certain assumptions. According to 
society that is often referred to as "deadweight loss." ${ }^{\text {"Imperfectly com- }}$ petitive criminal markets are more difficult to evaluate. On the one hand, imperfect criminal markets in which sellers possess pricing power likely underproduce crime ${ }^{98}$ Given the negative impact of crime on social welfare, this would suggest that an imperfect criminal market is preferable to a perfectly competitive one. Similarly, some have suggested that criminal monopolists and cartels have both the incentive and the ability to impose a certain level of discipline over criminal activities that is good both for business and for society as a whole. ${ }^{99}$ For example, centralized criminal enterprises may recognize that the sale of drugs to children or the execution of witnesses during a freight hijacking can trigger undesirable police attention and a political backlash that impose substantial costs on their other criminal activities. ${ }^{100}$ In this respect, the public is likely to prefer criminal activity in an imperfectly competitive market to less "organized" crime.

Unfortunately, there are also significant costs associated with imperfect criminal markets. Because producers in imperfect markets make outsized profits, imperfect criminal markets are full of incentives for criminals to enter and fight for market position. ${ }^{101}$ The negative externalities associated with the violent struggle for control of the market may well outweigh the benefits (or reduced costs) that flow from the underproduction of crime. ${ }^{102}$ Moreover, it is not necessarily the case that in-

the theory of the "second best," it is possible that, in a world in which all markets are equally imperfect, resources can be allocated efficiently. See Posner, Economic Analysis of Law, supra note $5, \S 9.3$, at 357 n.2.

97. Samuelson \& Nordhaus, supra note 59, at 200.

98. See Bushway \& Reuter, supra note 26, at 427 (" $[\mathrm{I}] \mathrm{n}$ legal markets there is a wellestablished doctrine that monopoly control or any suppression of competition hurts society ... . However, the state may actually find itself allied with cartel organizers in illegal markets, if that will result in higher prices and thus reduce the production of 'bads."'); see also James M. Buchanan, A Defense of Organized Crime?, in The Economics of Crime and Punishment 119, 119 (Simon Rottenberg ed., 1973) ("If monopoly in the supply of 'goods' is socially undesirable, monopoly in the supply of 'bads' should be socially desirable, precisely because of the output restriction.").

99. See, e.g., Thomas C. Schelling, Economics and Criminal Enterprise, Pub. Int., Spring 1967, at 61, 73 (arguing "organization" of criminal activity may reduce negative externalities).

100. Id.

101. See Bushway \& Reuter, supra note 26 , at 434 (noting prospect of monopoly power increases incentives to enter criminal markets); see also Levitt \& Venkatesh, supra note 91, at 772-73 (describing drug market as "tournament" rewarding successful utilization of violence); Abdala Mansour, Nicolas Marceau \& Steeve Mongrain, Gangs and Crime Deterrence, 22 J.L. Econ. \& Org. 315, 319 (2006) (observing that reduced competition in criminal market may result in more violence because there are significant profits at stake).

102. See Jonathan P. Caulkins, Peter Reuter \& Lowell J. Taylor, Can Supply Restrictions Lower Price? Violence, Drug Dealing and Positional Advantage, 5 Contributions to Econ. Analysis \& Pol'y, no. 1, art. 3, 2006, at 2, http://www.degruyter.com/view/j/ bejeap.2005.5.issue-1/bejeap.2006.5.1.1387/bejeap.2006.5.1.1387.xml (on file with the 
creased centralization will reduce the number of crimes committed. If centralization reduces the transaction costs associated with coordinating other criminal ventures, a reduction in the number of criminals (or criminal organizations) might result in an increase in the total quantity of crimes committed. Criminal monopolies can impose other costs on society as well. The successful commission of some crimes (such as some forms of extortion) may require significant resources available only to criminal enterprises of substantial size and strength. Similarly, criminal cartels and monopolies are in a better position to corrupt local law enforcement and other public officials. ${ }^{103}$

It is difficult, if not impossible, to determine with certainty whether society is better off with a centralized, imperfectly competitive criminal market or one that is characterized by many small criminal organizations with little individual control over the total quantity of crime produced. However, the difficulty in ascertaining the costs and benefits of competition in criminal markets does not make criminal market structure irrelevant. The structure of a criminal market clearly has a significant impact on the level of harm inflicted upon society. Consequently, it is appropriate to identify the impact that second-order crimes may have on the structure of criminal markets. ${ }^{104}$

The most obvious second-order crime affecting criminal market structure is the use of violence (often gun violence) to reduce competition in a first-order criminal market. ${ }^{105}$ It is not uncommon for criminals to use guns and gun violence to suppress competition and increase their market power. ${ }^{106}$ In their analysis of the finances of a drug-selling gang, economists Steven Levitt and Sudhir Venkatesh observed that a violent gang war can substantially increase the prevailing gang's influence over

Columbia Law Review) (describing "socially counter-productive effect" of policies that raise drug prices and thus incentivize drug-related violence).

103. See Schelling, supra note 99 , at 66 (describing advantages of scale and ability of large firms to "cultivat[e] relations with the police"); id. at 77 (explaining monopolies' incentive to corrupt officials).

104. One should not assume that all criminal markets are imperfect in an economic sense. In fact, evidence suggests that many criminal markets, in particular many local drug markets, are in fact highly competitive, and sellers often do not have significant influence over price. See Reuter \& Caulkins, Illegal Lemons, supra note 43, at $147 \mathrm{n}$.* ("[I]llicit drug markets are rarely subject to monopoly or cartel arrangements [because] exclusion is too difficult."); see also Reuter, Illegal Markets, supra note 36, at x (concluding that economic and institutional constraints limit ability of criminal enterprises to restrain competition and establish dominance in many illegal markets).

105. These are second-order crimes because the motivation for illegally possessing and using guns would not exist but for the criminal organization's interest in gaining market position in the first-order criminal market.

106. See Mansour et al., supra note 101 , at 319 ("[C] riminal organizations can use violence to maintain their market power."); Lawrence Rosenthal, Pragmatism, Originalism, Race, and the Case Against Terry v. Ohio, 43 Tex. Tech L. Rev. 299, 310 (2010) (describing use of violent intimidation by street gangs to suppress competition in local drug markets). 
the price of illegal drugs. They observed that the gang in their study was able to charge substantially higher prices for crack cocaine following a gang war that effectively doubled the area under their control. ${ }^{107}$ The use of violence to seize "drug turf," like other second-order crimes, imposes significant costs on society. It also, however, creates inefficiencies in the first-order drug market. The violent consolidation of the drug market raises drug prices and reduces the total quantity of drugs sold. ${ }^{108}$

Policymakers thus face a difficult choice. By intervening to prevent the second-order crime of drug related violence, policymakers inadvertently perfect the first-order illegal drug market-increasing its efficiency, lowering the price of illegal drugs, and, ultimately, increasing the quantity of drugs sold.

\section{B. How the Criminalization of Second-Order Crimes Perfects First-Order Criminal Markets}

If second-order crimes can engender inefficiency and weakness in first-order criminal markets, it is not surprising that efforts to suppress second-order crimes can inadvertently bolster those first-order criminal markets. Indeed, it seems likely that policymakers "perfect" first-order criminal markets across a broad spectrum of illegal activity. From prostitution to drug markets to back-alley abortions, second-order crimes create problems for first-order criminal markets. By criminalizing related activities, policymakers inadvertently resolve information asymmetries, strengthen competition, and eliminate costs that hinder first-order criminal markets.

Lawmakers may rationally criminalize the sale of fake drugs to deter the violence that results when dealers defraud their customers. ${ }^{109}$ However, in doing so, they also reduce the asymmetry of information between dealers and buyers that weakens the genuine illicit drug market. Counterfeit prescription drugs offer a related example. While they represent a

107. Levitt \& Venkatesh, supra note 91 , at 768 ; see also Lawrence Rosenthal, Second Amendment Plumbing After Heller. Of Standards of Scrutiny, Incorporation, WellRegulated Militias, and Criminal Street Gangs, 41 Urb. Law. 1, 13 (2009) (" $[E]$ thnographic research on gang crime concludes that gangs endeavor to organize drug markets in order to maximize the economic benefits of drug dealing while using the threat of violence to police competition.").

108. As discussed, it is difficult to ultimately quantify the total impact of a rise in drug prices on total crime. Estimates of the price elasticity of demand for drugs like cocaine vary substantially. Some estimates suggest that demand is highly inelastic, while others indicate that demand is quite sensitive to changes in price. See Bushway \& Reuter, supra note 26 , at 429 (" $[\mathrm{E}]$ stimates for the price elasticity of the demand for cocaine vary between -0.6 and -2.5 ."). Furthermore, even if a rise in prices substantially reduces drug consumption, the total quantity of crimes in the community will not necessarily decline. Users may well commit additional property crimes to fund their addiction. As a result, while the number of drug sales might fall, the crime rate could rise.

109. See supra notes $45-49$ and accompanying text (discussing violent "self-help" countermeasures associated with fake drug sales). 
very real health threat, ${ }^{110}$ laws that enhance the penalties for serious injuries or deaths resulting from trafficking in counterfeit goods actually increase buyers' confidence that the counterfeit drugs they purchase will not harm them. ${ }^{111}$

Sometimes second-order criminalization can correct multiple firstorder market problems. With the exception of some counties in Nevada, prostitution is a crime everywhere in the United States. ${ }^{112}$ Among the many problems associated with prostitution is the concern that "sex work" contributes to the spread of HIV/AIDS. ${ }^{113}$ Notably, the criminalization of prostitution is a good example of how first-order crimes can create second-order problems by deregulating a market. By driving underground an industry that might otherwise have been regulated to prevent the spread of communicable disease, the criminalization of prostitution created a secondary problem - the spread of HIV/AIDS through illegal sex work. ${ }^{114}$ True to form, legislatures across the country have responded to this secondary problem with new statutes criminalizing prostitution with the knowledge that the defendant was aware that he or she had tested positive for HIV.115

As discussed below, one might question whether the second-order crime, "HIV-aware prostitution," actually deters HIV-positive individuals

110. See, e.g., Counterfeit Version of Avastin in U.S. Distribution, supra note 40 (describing danger posed by counterfeit versions of cancer drug Avastin).

111. Cf. 18 U.S.C.A. $\$ 2320$ (b) (2) (West Supp. 2012) (increasing maximum penalty for trafficking in counterfeit goods to twenty years if defendant's conduct recklessly causes serious bodily injury and to life sentence if defendant's conduct recklessly causes death).

112. Nicole Bingham, Nevada Sex Trade: A Gamble for the Workers, 10 Yale J.L. \& Feminism 69, 69 \& n.1 (1998) (listing state statutes).

113. See United States Leadership Against HIV/AIDS, Tuberculosis, and Malaria Act of $2003 \S 2$ (23), 22 U.S.C. $\$ 7601$ (23) (2006) (finding that prostitution and sex trafficking are "causes of and factors in the spread of the HIV/AIDS epidemic"); see also Bingham, supra note 112, at 95 ("Historically, prostitutes have been scapegoated for the spread of venereal disease.").

114. In Nevada, the one state that allows local communities to legalize prostitution, individuals engaged in prostitution are required by both statute and the Nevada Administrative Code to submit to HIV testing. Bingham, supra note 112, at 89 . An eighteen-month mandatory testing program of the state did not reveal any licensed prostitutes who tested positive for HIV. James Grant Snell, Note, Mandatory HIV Testing and Prostitution: The World's Oldest Profession and the World's Newest Deadly Disease, 45 Hastings L.J. 1565, 1591 n.161 (1994) (citing No Infection in Nevada Brothels, N.Y. Times, Nov. 3, 1987, at C3).

115. See, e.g., Cal. Penal Code $\$ 647 \mathrm{f}$ (West 2010) (making prostitution a felony on second offense if defendant knew that he or she had tested positive for HIV); accord, e.g., Colo. Rev. Stat. Ann. \& 18-7-201.7 (West 2004); Fla. Stat. Ann. § 796.08(4) (West Supp. 2012); Ky. Rev. Stat. Ann. \$529.090 (3) (LexisNexis 2008); Mo. Ann. Stat. \$ 567.020 (West 2012); Nev. Rev. Stat. Ann. \$ 201.358 (LexisNexis 2012); Ohio Rev. Code Ann. $\$ 2907.25$ (C) (2) (West 2006); Okla. Stat. Ann. tit. 21, § 1031(B) (West 2002); 18 Pa. Cons. Stat. Ann. § 5902(a.1)(4) (West Supp. 2012); Tenn. Code Ann. § 39-13-516 (2010); Utah Code Ann. $\$ 76-10-1309$ (1) (LexisNexis Supp. 2012). 
from engaging in prostitution. ${ }^{116}$ To the degree that the statute either has such an impact or is perceived as having such an impact, it decreases the apparent danger (that is, lowers the costs) of utilizing the services of a prostitute. Moreover, by harshly penalizing HIV-aware prostitution, legislatures may be eliminating an asymmetry of information between "johns" and prostitutes that might impede an "efficient" exchange of money for services.

The complex and tragic context in which an HIV-positive sex worker sells her ${ }^{117}$ services is wholly different from the used car salesman who hawks low quality automobiles. However, just as car buyers might fear that they are purchasing "lemons," so too might johns be concerned that they are purchasing sex from infected prostitutes. By raising the stakes of engaging in HIV-positive prostitution, the HIV-aware prostitution statutes decrease buyers' concerns that prostitutes are hiding their HIV-positive condition.

That HIV-aware prostitution statutes may be perfecting the firstorder market for prostitution is all the more troubling if these laws do not actually decrease the incidence of HIV-infected individuals engaging in prostitution. ${ }^{118}$ First, there is the possibility that the statutes will deter prostitutes from getting tested. ${ }^{119}$ Second, and perhaps more likely given the context in which many prostitutes are making the decision to enter into the sex trade, few HIV-positive sex workers may be deterred from engaging in prostitution by the increase in penalties associated with the statute. If clients incorrectly believe that the HIV-positive statutes are effective, it is possible that the statutes will improve the first-order prostitution market without actually lowering the risk of contracting HIV.

Like the prostitution example, laws enhancing penalties for illegal abortions that result in the death of the mother may actually improve the market for the first-order crime of providing illegal abortions. While Roe $v$. Wade and its progeny held that a woman's right to an abortion is protected in the first two trimesters, some abortion services can still be crim-

116. See Scott Burris, Leo Beletsky, Joseph Burleson, Patricia Case \& Zita Lazzarini, Do Criminal Laws Influence HIV Risk Behavior? An Empirical Trial, 39 Ariz. St. L.J. 467, 471 (2007) (concluding that criminal law has little influence on sexual risk behavior); Zita Lazzarini, Sarah Bray \& Scott Burris, Evaluating the Impact of Criminal Laws on HIV Risk Behavior, 30 J.L. Med. \& Ethics 239, 252 (2002) (arguing that case for "criminal law as a means of preventing HIV . . looks weak").

117. Although the female pronoun is used here, the same concerns about HIV transmission also affect the substantial market for male prostitutes.

118. See Lazzarini et al., supra note 116, at 247 (noting research showing lack of change in behavior of HIV-positive individuals).

119. See Michael L. Closen, Mary Anne Bobinski, Donald H.J. Hermann, John F. Hernandez, Gene P. Schultz \& J. Kelly Strader, Discussion, Criminalization of an Epidemic: HIV-AIDS and Criminal Exposure Laws, 46 Ark. L. Rev. 921, 964 (1994) ("Therefore, these statutes may actually encourage individuals not to test so that they would not be armed with knowledge that, at another time, could be used against them." (statement of John F. Hernandez)). 
inalized. ${ }^{120}$ Forty-one states criminalize abortions after a certain point in the pregnancy. ${ }^{121}$ Nearly forty states criminalize abortions performed by someone other than a doctor. ${ }^{122} \mathrm{~A}$ variety of factors may contribute to a woman's decision to pursue an illegal abortion. The pregnancy may simply have progressed to the point beyond which abortion has been criminalized. Young women required to notify their parents that they plan to terminate their pregnancy may instead seek to obtain one on the black market. ${ }^{123}$ Financial pressure may also contribute to the decision to seek an illegal abortion. While the nature of illegal markets tends to make data imprecise, ${ }^{124}$ one study has suggested that states that restricted funding for abortion services experienced a significant rise in the number of illegal abortions. ${ }^{125}$

The substantial health risks associated with illegally terminating a pregnancy likely act as a significant deterrent to pursuing a black-market abortion: Individuals providing illegal abortion services are likely to have inferior medical training; the procedures are likely to be performed in unsanitary conditions; and there tend to be fewer opportunities for follow-up care. ${ }^{126}$ The provision of black market abortions is not only illegal, it can also be hazardous to the mother's health. The criminalization

120. See, e.g., Roe v. Wade, 410 U.S. 113, 164-65 (1973) (permitting state regulation and prohibition of abortion under certain circumstances); Gonzales v. Carhart, 550 U.S. $124,156-60$ (2007) (upholding criminalization of partial-birth abortion method as legitimate exercise of legislative discretion).

121. State Policies in Brief: State Policies on Later Abortion, Guttmacher Inst., (Oct. 1, 2012), http://www.guttmacher.org/statecenter/spibs/spib_PLTA.pdf (on file with the Columbia Law Review).

122. E.g., Cal. Health \& Safety Code $\$ 123468(a)$ (West 2012); Colo. Rev. Stat. Ann. $\$$ 18-6-101(1), -102 (West 2004); Fla. Stat. Ann. \$ 390.0111(2) (West Supp. 2012); Idaho Code Ann. \$ 18-608A (2004); Ky. Rev. Stat. Ann. \$311.750 (LexisNexis 2011); Me. Rev. Stat. Ann. tit. 22, $\$ 1598(3)$ (2004); Md. Code Ann., Health-Gen. $\$ 20-208$ (LexisNexis 2009); Mont. Code Ann. \$ 50-20-109(a) (2011); N.Y. Penal Law § 125.05(3) (McKinney 2009); Tex. Health \& Safety Code Ann. $\$ 171.003$ (West 2010).

123. See Karen Flax, Comment, Women's Rights and the Proposed Family Protection Act, 36 U. Miami L. Rev. 141, 151 (1981) (describing concern that pregnant minors will "attempt to self-abort or to obtain an illegal abortion rather than risk parental notification").

124. See Richard W. Bourne, Abortion in 1938 and Today: Plus Ca Change, Plus C'est la Même Chose, 12 S. Cal. Rev. L. \& Women's Stud. 225, 273 (2003) (describing difficulty of obtaining data on illegal abortion).

125. See Nancy Binkin, Julian Gold \& Willard Cates Jr., Illegal Abortion Deaths in the United States: Why Are They Still Occurring?, 14 Fam. Plan. Persp. 163, 166 (1982) (concluding that restrictive funding policies contributed to higher rate of illegal abortions and concomitant higher rate of illegal abortion-related deaths).

126. See Gail D. Hollister, Tort Suits for Injuries Sustained During Illegal Abortions: The Effects of Judicial Bias, 45 Vill. L. Rev. 387, 421 (2000) (identifying health dangers of illegal abortions); see also William Cates, Jr., David A. Grimes \& Kenneth F. Schulz, The Public Health Impact of Legal Abortion: 30 Years Later, 35 Persp. on Sexual \& Reprod. Health 25, 27 (2003) (noting reduced morbidity and mortality following increased availability of legal abortion). 
of abortions thus leads to a second-order crime-deaths resulting from illegal abortions.

Eight states have laws that enhance the penalties for criminal abortions that result in the death of the woman. ${ }^{127}$ Under Florida law, the unlawful termination of a pregnancy in the third trimester is classified as a third-degree felony. ${ }^{128}$ An unlawful termination is a second-degree felony, however, if it results in the death of the patient. ${ }^{129}$ By increasing the penalty for performing an illegal abortion in which the patient dies, the law is designed to encourage illegal abortion providers to take greater safety precautions. However, just as the HIV-aware prostitution statutes reduce the perceived risk of engaging the services of a prostitute, so too do the penalty enhancements for abortions resulting in death improve the market for illegal abortions. That the penalty enhancements help to perfect the market for illegal abortions does not necessarily suggest that they are inappropriate. Rather, it serves as a reminder of how complex and difficult the criminalization of related crimes can be.

The criminalization of second-order crimes can even resolve collective action problems that create inefficiencies in first-order criminal markets. As discussed above, a drug dealer's decision to arm himself may represent his response to a classic prisoner's dilemma-there are significant benefits to arming oneself when others go unprotected, and significant dangers to encountering someone else with a gun while one is unarmed. ${ }^{130}$ As a result, every dealer goes armed despite preferring a market in which no one carries a gun. Moreover, the prevalence of guns (and thus gun violence) likely increases the cost of participating in illegal drug markets, thereby reducing both the supply and demand for drugs. ${ }^{131}$

In 1986, Congress added an important new weapon against narcotics traffickers by mandating a minimum five-year sentence for using or carrying a firearm during or in relation to a drug trafficking crime ${ }^{182}$ The decision to enhance the penalty for armed drug trafficking as opposed to drug dealing in general suggests that the goal of the statute was to deter

127. Colo. Rev. Stat. Ann. \$ 18-6-102; Fla. Stat. Ann. \$ 390.0111(10) (b); Mich. Comp. Laws. Ann. § 750.14 (West 2004); Miss. Code Ann. § 97-3-3(1) (2006); N.M. Stat. Ann. \$ 30-5-3 (2004); N.Y. Penal Law $\$ 125.20(3)$; Vt. Stat. Ann. tit. 13, § 101 (2009); W. Va. Code Ann. $\$ 61-2-8$ (LexisNexis 2010).

128. Fla. Stat. Ann. $\$ 390.0111(10)(a)$.

129. Id. § 390.0111 (10) (b).

130. See supra notes 87-88 and accompanying text (describing gun possession among criminals as prisoner's dilemma).

131. See supra notes 89-92 and accompanying text (discussing effect of gun possession on supply and demand for illegal goods).

132. Firearms Owners' Protection Act, Pub. L. No. 99-308, $\$ 104$ (a) (2), 100 Stat. 449, 456-57 (codified at 18 U.S.C. $\$ 924(\mathrm{c})(1)(\mathrm{A})$ ). For a detailed discussion of the background of $\$ 924$ (c) (1), see generally Michael J. Riordan, Using a Firearm During and in Relation to a Drug Trafficking Crime: Defining the Elements of the Mandatory Sentencing Provision of 18 USC $\$ 924$ (c) (1), 30 Duq. L. Rev. 39, 39-43 (1991). 
gun violence as opposed to simply providing another weapon for the war on drugs. Ironically, it is conceivable that the act was welcomed by drug dealers. By raising the cost of carrying a firearm during a narcotics transaction, Congress may have helped resolve dealers' prisoner's dilemma and promoted the kind of cooperation that lowers the cost of engaging in illegal drug activity.

\section{IMPLICATIONS OF PERFECTING CRIMINAL. MARKETS}

If lawmakers are, in fact, inadvertently perfecting first-order criminal markets, the inevitable question is: Does it matter? Surely the need to prevent street violence justifies criminalizing the sale of fake drugs, even if one side effect of such a ban is to improve the first-order drug market.

The answer is that the relationship between first- and second-order criminal markets is important even if the criminalization of both activities can ultimately be justified. The perfection of criminal markets is not just a quirky economic irony, but rather an important systemic dynamic with broad implications. An appreciation of the relationship between first- and second-order crimes is not only essential to the formation of sound criminal justice policy, but it may also help explain the rapid expansion of the criminal code and the growing complexity of federal and state sentencing guidelines. Moreover, the recognition that criminalization has the capacity to actually improve related criminal markets may promote a normative shift in the perception of regulatory alternatives to criminalization.

Regulatory strategies that reduce harm are often criticized for helping individuals engage in socially undesirable behavior. ${ }^{133}$ If the criminal law similarly "assists" other antisocial activity, then perhaps those harmreduction strategies will no longer be accused of tacitly condoning bad acts and instead the costs and benefits of such policies will be evaluated on the same footing as the criminalization option.

133. See, e.g., Lawrence O. Gostin \& Zita Lazzarini, Prevention of HIV/AIDS Among Injection Drug Users: The Theory and Science of Public Health and Criminal Justice Approaches to Disease Prevention, 46 Emory L.J. 587, 645-46 (1997) ("[Opponents of needle exchange programs] believe that the state should send a consistent message about the harms of drug use and should not directly facilitate drug injection. . . When the state permits or condones the distribution and sale of syringes ... arguably, the state is engaging in an immoral act."); Can Clean Needles Slow the AIDS Epidemic?, 59 Consumer Rep. 466, 467 (1994) ("Distributing needles 'undercuts the credibility of society's message that drug use is illegal and morally wrong' ...." (quoting Robert Martinez, Dir. of Pres. George H.W. Bush's Office of Nat'l Drug Control Policy)); see also Steven R. Salbu, Needle Exchange, HIV Transmission, and Illegal Drug Use: Informing Law and Public Policy with Science and Rational Discourse, 33 Harv. J. on Legis. 105, 126 (1996) ("Christine Whitman, the governor of New Jersey, has stated that she is opposed to needle exchanges "because she "doesn't want to be a party to an illegal activity." (quoting Clean Needles Are Vital in the Fight Against AIDS, Record (Bergen County, N.J.), Mar. 22, 1995, at C6)). 
The remainder of this Part proceeds as follows. Part III.A explores policy implications of perfecting criminal markets for legislators, judges, prosecutors, and members of law enforcement. Part III.B then suggests that the dynamic relationship between first- and second-order criminal markets may help to explain both the rapid growth in state and federal criminal codes and the concomitant expansion of criminal liability that has led some scholars to argue that we face a crisis of overcriminalization. ${ }^{134}$ Finally, Part III.C examines normative implications of the fact that criminalizing second-order antisocial activities may improve firstorder criminal markets.

\section{A. Perfecting Criminal Justice Policy}

The possibility that legislators are inadvertently increasing criminal activity has profound implications for criminal justice policy. While there is growing recognition that institutional interests play a significant role in shaping criminal laws, ${ }^{135}$ few scholars dismiss the claim that legislators generally seek to act in the public's interest. ${ }^{136}$ Even those critics who allege that many recent federal and state criminal justice initiatives are "contrary to what almost everyone with close knowledge of the topic thinks makes much sense" do not attribute the failings of the criminal justice system to bad intentions. ${ }^{137}$ In fact, evidence suggests that persuasive policy arguments that are grounded in concerns shared by the general public can have a powerful influence on legislators. ${ }^{138}$ As a result, lawmakers are likely to be particularly interested to learn that the criminalization of one activity may improve a related criminal market.

Moreover, there are increasingly urgent calls for other actors in the criminal justice system-prosecutors, judges, and law enforcement offi-

134. Sanford H. Kadish, The Crisis of Overcriminalization, 374 Annals Am. Acad. Pol. \& Soc. Sci., 157, 157 (1967).

135. See Stuntz, supra note 8, at 510 (describing prosecutors' and legislators' institutional incentives to push for policies which consistently expand criminal liability).

136. See id. (acknowledging that criminal justice policies can be powerfully affected by ideology and public-interest goals, despite role institutional interests often play in pathological politics of criminal law).

137. Beale, Non-Legal Factors, supra note 8, at 23 (quoting Howard Margolis, Dealing with Risk: Why the Public and the Experts Disagree on Environmental Issues 5 (1996)). Beale, who attempts to explain the politicization of crime and prevalence of counterproductive criminal justice policies, acknowledges that some scholars have challenged her claim that current criminal justice policies are irrational, arguing "that the majority of experts are wrong and that the public is indeed correct." Id. at 32 (citing John J. Dilulio, Jr., Help Wanted: Economists, Crime and Public Policy, 10 J. Econ. Persp. 3, 1215 (1996); James Q. Wilson, Crime and Public Policy, in Crime 449, 498-503 (James Q. Wilson \& Joan Petersilia eds., 1995)).

138. See Rachel E. Barkow, Administering Crime, 52 UCLA L. Rev. 715, 719-20 (2005) (concluding legislators can be swayed by policy arguments grounded in concerns shared by general public). 
cials-to rationalize their own decisionmaking processes. ${ }^{139}$ Just as understanding the dynamics of first- and second-order criminal markets will help legislators make informed decisions, so too can it help these actors improve the implementation of criminal justice policy. Indeed, even if legislators and other criminal justice actors choose not to take the impact of first- and second-order crimes on each other into account when they make policy decisions, drawing attention to the capacity of second-order crimes to perfect first-order criminal markets can still improve criminal justice policy by encouraging policymakers to incorporate cost-benefit analysis in to their decisionmaking.

1. Cost-Benefit Analysis and Criminal Law. - Criminal laws are rarely evaluated based on their broad social impact. Instead, a criminal law is typically assessed in terms of the particular harm caused by the offender and the goals of deterrence, retribution, and moral judgment. ${ }^{140}$ This focus alone may explain the failure of commentators and policymakers alike to recognize the critical relationship between first- and secondorder criminal markets. However, there is growing recognition that policymakers face multiple options for combating criminal harms and that the larger question of the public's welfare is an important consideration in determining which strategy to pursue. ${ }^{141}$ While the criminal justice system has yet to embrace cost-benefit analysis as a methodology for evaluating criminal law and policy, other regulatory regimes have adopted it as a useful mechanism for "improving the effectiveness of government action." ${ }^{142}$ There is a mounting consensus that criminal policies need to be more rational and that an attempt to fully assess the social costs and benefits of criminal laws, while daunting, may be productive nonetheless. ${ }^{143}$ Even if policymakers, prosecutors, judges, and members of the law enforcement community refrain from formally adopting cost-benefit analysis, to the extent they want to evaluate the broad impact of their

139. See Darryl K. Brown, Cost-Benefit Analysis in Criminal Law, 92 Calif. L. Rev. 323, 341 (2004) [hereinafter Brown, Cost-Benefit Analysis] (arguing cost-benefit analysis "can rationalize decision making in criminal law by correcting biases that lead to poor public policy and accounting for costs that criminal law neglects").

140. See id. at 335 ("We do not usually focus on criminal law as part of a complex system with multiple cause-and-effect relationships. Instead, we focus on the state's response to individual offenders and the direct harm caused by the offense.").

141. See id. at 326 (observing that "criminal law is only one policy option for dealing with harmful wrongdoing").

142. Id. at 333; see also Cass R. Sunstein, Congress, Constitutional Moments, and the Cost-Benefit State, 48 Stan. L. Rev. 247, 252 (1996) (describing advantages of "cost-benefit state" but also suggesting officials must be nuanced in their approach to assigning value).

143. Rachel E. Barkow, Our Federal System of Sentencing, 58 Stan. L. Rev. 119, 129 (2005) (arguing cost-benefit analysis could improve decisionmaking about sentencing); see also Brown, Cost-Benefit Analysis, supra note 139, at 343 (arguing cost-benefit analysis can lead decisionmakers to "uncover costs not now readily attributed to criminal justice policy"). 
choices on social welfare, they must take into account the dynamic relationship between first- and second-order criminal markets.

2. Perfecting the Legislative Process. - The possibility that new penal statutes will improve related criminal markets should certainly be of interest to legislators as they seek to promote the public interest. First, legislators choosing among various policy options will be interested to learn that some criminal statutes carry hidden costs that may offset some of the public safety benefits that the laws were intended to engender. By taking into account a proposed statute's impact on second-order criminal markets, a legislature will be better equipped to decide whether the statute will actually promote the public interest. More importantly, by understanding the relationship between first- and second-order criminal markets, a legislature can begin to calibrate the penalties associated with each criminal statute. While economists (and law scholars who consider themselves economists) have long advocated for "optimal" penalties that are calculated to deter crime efficiently, ${ }^{144}$ such proposals realistically are difficult to implement. ${ }^{145}$ It is one thing to develop a formula which, if theoretically optimized, would lead to an efficient level of crime. It is another thing entirely to identify actual values for the formula's variables and to calculate an appropriate sanction. By recognizing the dynamic relationship between first- and second-order crimes, legislators can begin to fashion a more integrated structure of criminal sanctions. If criminalizing the sale of fake illegal drugs inadvertently improves the market for genuine drugs, a legislature might consider offsetting the impact of the new law by strengthening the penalty for the first-order crime. The result is a system of penal sanctions that, while perhaps not truly "optimized" to produce the most efficient level of crime, at least are structured to work together in concert.

Focusing legislative attention on the potential for second-order crimes to perfect first-order criminal markets may have the added benefit of shifting the political discourse in a way that will promote more rational criminal justice policies. For several decades, ${ }^{146}$ the politics of crime have

144. E.g., Becker, supra note 5, at 172; A. Mitchell Polinsky \& Steven Shavell, The Optimal Use of Fines and Imprisonment, 24 J. Pub. Econ. 89, 89-90 (1984) (introducing model to measure optimal use of sanctions). The idea that criminal penalties should be calculated to provide sufficient incentive to deter crime dates (at least) to Jeremy Bentham, who suggested that "the quantity of punishment must not be less, in any case, than what is sufficient to outweigh the profit of the offence." Jeremy Bentham, An Introduction to the Principles of Morals and Legislation 175 (J.H. Burns \& H.L.A. Hart eds., The Athlone Press 1970) (1789); accord Jeremy Bentham, Principles of Penal Law, in 1 The Works of Jeremy Bentham 365, 399 (photo. reprint 1962) (John Bowring ed., 1843).

145. See Paul H. Robinson \& John M. Darley, The Role of Deterrence in the Formulation of Criminal Law Rules: At Its Worst When Doing Its Best, 91 Geo. LJ. 949, 977-80 (2003) (describing many complex variables making it difficult to calculate optimal punishment).

146. Some observers trace the politicization of the crime issue to Richard Nixon's successful promotion of his "law and order platform" in 1968. See Harry A. Chernoff, 
been dominated by forces which tend to promote punitive approaches that have been regarded as unproductive by many criminal justice experts. ${ }^{147}$ Several scholars have suggested that the perceived need for politicians to appear "tough on crime," 148 and the "culture of fear" created by the graphic depictions of crime in news and entertainment media ${ }^{149}$ have combined to ensure that the consistent political response to crime is to increase sanctions and expand criminal liability. ${ }^{150}$ More recently, psychological research has identified various cognitive biases which amplify these forces, further distorting criminal justice policy in ways that are ultimately unlikely to increase public safety. ${ }^{151}$ Cognitive errors resulting from the "availability heuristic," ${ }^{52}$ overconfidence, ${ }^{153}$ overgeneralization, ${ }^{154}$ inaccurate estimation of risks and benefits, ${ }^{155}$ and biased infor-

Christopher M. Kelly \& John R. Kroger, The Politics of Crime, 33 Harv. J. on Legis. 527, 532-33 (1996) (noting that since 1968, "Republican Presidents and presidential nominees have used the crime issue to put Democrats on the defensive").

147. See Beale, Non-Legal Factors, supra note 8, at 25 (noting low support among criminal justice experts for increased sentences); see also Michael Tonry \& David P. Farrington, Strategic Approaches to Crime Prevention, 19 Crime \& Just. 1, 6 (1995) (citing studies showing "widespread agreement over time and space that alterations in sanctioning policies are unlikely substantially to influence crime rates").

148. E.g., Chernoff et al., supra note 146, at 532-34 (discussing political advantage of support for "tougher" penalties).

149. See Beale, Non-Legal Factors, supra note 8, at $45-47$ (describing meteoric rise of depictions of crime in news media and development of industry adage "[i]f it bleeds, it leads"); see also Jonathon Simon, Governing Through Crime: How the War on Crime Transformed American Democracy and Created a Culture of Fear 114, 208, 239 (2007) (describing how media images of crime have created public perception of extreme danger of criminal violence in many aspects of daily life).

150. See Beale, Non-Legal Factors, supra note 8, at 40-41, 49 (describing political rhetoric and media influence as two explanations of punitive nature of American criminal justice policy).

151. See id. at 52 (suggesting that psychology of cognition and risk assessment may explain divergence between public and expert opinion on criminal justice policy); Brown, Cost-Benefit Analysis, supra note 139, at 341-42 (describing how cognitive bias skews judgments about criminal law and policy).

152. The "availability heuristic" describes people's perception of events as more probable if there is a vivid example of the event. Brown, Cost-Benefit Analysis, supra note 139 , at 342 . For example, members of the general public may overestimate the probability of being killed in a terrorist attack because of the vivid example of September 11th.

153. "Overconfidence" describes the tendency for people to base opinions on slim information with great confidence and subsequently to resist indications that the initial opinion was incorrect. Beale, Non-Legal Factors, supra note 8, at 59.

154. "Overgeneralization" describes the excessive degree to which people base general theories on a few examples or even a single example. For example, "[h]earing about one parolee committing a violent crime is likely to foster generalization to all parolees, with the result that most people will overestimate by a considerable margin the failure rates for parole.” Julian V. Roberts, Public Opinion, Crime, and Criminal Justice, 16 Crime \& Just. 99, 121 (1992).

155. Studies have demonstrated that people often underestimate risks when the benefits of an activity seem clear and high and underestimate benefits when risks are perceived as high. Brown, Cost-Benefit Analysis, supra note 139, at 342; see also Cass R. 
mation processing ${ }^{156}$ combine to skew judgments in ways that are unlikely to produce effective criminal justice policy. Fortunately, a deliberate and careful consideration of costs and benefits can provide an institutional check on the cognitive biases that often distort policy decisions. ${ }^{157}$

Focusing policymakers on second-order crimes' impact on firstorder criminal markets can supplement and encourage the kind of rational cost-benefit analysis that is likely to result in better policy choices. This is not to say that cost-benefit analysis should entirely substitute for the intuitive moral judgments of policymakers. ${ }^{158}$ But it does suggest that increased attention to some of the overlooked costs of criminalization will do more than just incrementally add to the information at policymakers' disposal; it will actually encourage a type of analysis that is resistant to cognitive error.

3. Perfecting the Implementation of Criminal Justice Policy. - Even if legislators attempt to internalize the impact of second-order crimes on firstorder criminal markets by adjusting the crimes' respective penalties, the prices they set for crimes are, at best, "suggested retail prices." In fact, the true price of crime is shaped as much by the actors who implement criminal justice policy as it is by the policymakers themselves. ${ }^{159}$ Focusing attention on the potential for second-order crimes to perfect first-order

Sunstein, Cognition and Cost-Benefit Analysis, 29 J. Legal Stud. 1059, 1070 (2000) [hereinafter Sunstein, Cognition and CBA] ("The mere existence of discussions of new risks can aggravate concern, even when the discussions take the form of assurances that the risk level is relatively low.").

156. "Biased information processing" describes the tendency of individuals to discount new information that challenges their existing beliefs and, similarly, their tendency to give significant credence to information that confirms views they already hold. Beale, Non-Legal Factors, supra note 8, at 59-60; Roberts, supra note 154, at 123-24.

157. Rachel E. Barkow, Federalism and the Politics of Sentencing, 105 Colum. L. Rev. 1276, 1294 (2005); see also Brown, Cost-Benefit Analysis, supra note 139, at 341 ("[Costbenefit analysis] can rationalize decision making in criminal law by correcting biases that lead to poor public policy and accounting for costs that criminal law neglects."); Sunstein, Cognition and CBA, supra note 155, at 1071 ("[C]ost-benefit analysis might ensure that policy is driven not by hysteria or unfounded alarm but by a full appreciation of the effects of relevant risks and their control.").

158. See Alan Gibbard, Risk and Value, in Values at Risk 94, 98 (Douglas MacLean ed., 1986) ("A refined risk-cost-benefit analysis, because it is sensitive to details of the situation in a way that no person's intuitive picture of the situation could be, cannot be expected to match a person's clear moral judgments in every case ....").

159. Ninety-five percent of criminal cases are resolved with plea bargains. David A. Perez, Note, Deal or No Deal? Remedying Ineffective Assistance of Counsel During Plea Bargaining, 120 Yale L.J. 1532, 1539 (2011). While the plea bargaining process often does not entail the kind of individualized haggling that its name suggests, the generally accepted "price" for each crime is largely the product of prosecutorial policy and consistency with local sentencing tradition. See Gerard E. Lynch, Our Administrative System of Criminal Justice, 66 Fordham L. Rev. 2117, 2130-31 (1998) (explaining that rules of plea bargaining are "more like those of the supermarket than those of the flea market" and true "price" of crime is set by prosecutors, subject to efforts of defense attorneys to persuade them that more lenient approach is appropriate under circumstances). 
criminal markets can improve the implementation of criminal justice policy by helping such actors make more informed decisions and optimal allocations of limited resources.

a. Perfecting Prosecutors. - Prosecutors play a crucial role in determining the price of crime. They decide whether to initiate or decline a prosecution and whether to offer a defendant the chance to plead to a lesser charge. Prosecutors can recommend a particular sentence to a presiding judge and, in some jurisdictions, make a plea deal contingent upon that recommended sentence. ${ }^{160}$ Prosecutors also enjoy broad discretion to shape criminal justice priorities and to "move resources effectively from one area to another depending on social need." ${ }^{161}$ They can shape alternative sentencing opportunities by devising or influencing the development of drug and domestic violence treatment programs, juvenile justice facilities, and community-based courts linked to social service agencies. ${ }^{162}$ They also coordinate with law enforcement to set policing strategies. ${ }^{163}$ Each of these decisions impacts the price of crime by either changing the probability of being arrested and charged or by shifting the expected penalty that will be applied to those found guilty.

Because prosecutors play such an integral role in setting the price of crime, their decisions regarding one crime have reverberations in other criminal markets. If prosecutors routinely offer lenient pleas to defendants charged with selling fake narcotics, they will lessen the impact that the crime has on the first-order drug market. Conversely, the decision to prosecute a crime to the fullest extent of the law may have counterintuitive implications for the overall crime rate. As prosecutors make decisions concerning second-order crimes, they will want to consider carefully the impact those decisions have on related criminal markets.

Unlike many administrative actors, prosecutors are not obligated by statute to consider the costs and benefits of their decisions. ${ }^{164}$ This does not mean, however, that cost-benefit analysis cannot assist prosecutors as they implement criminal justice policy. Indeed, the Department of Justice has begun to incorporate an explicit accounting of the costs and

160. See, e.g., Md. R. 4-243(c) (3) (requiring consent of both parties before judge can offer disposition more favorable to defendant than provided for in plea agreement). Even in jurisdictions that do not explicitly require the judge to obtain the consent of the prosecutor before departing from the prosecutor's sentencing recommendation, it is rare for judges to depart from the agreed-upon sentence. See Ronald Wright \& Marc Miller, The Screening/Bargaining Tradeoff, 55 Stan. L. Rev. 29, 42, 88 (2002) (describing judges as part of system of "repeat players" who "have every reason to accept the recommendation from the parties to move the case along").

161. Lynch, supra note 159, at 2138.

162. Brown, Cost-Benefit Analysis, supra note 139, at 367 .

163. See id. at 369 (describing "how prosecutors can encourage and coordinate with law enforcement agencies to pursue criminal investigations through means that impose the social costs of punishment on stable rather than marginal communities").

164. See id. at 327 (observing that "analytic decision procedures ... ha[ve] not yet extended to the criminal justice system"). 
benefits of prosecutorial action in its own guidelines. ${ }^{165}$ Recognizing the dynamic relationship between first- and second-order criminal markets is an important step toward successfully utilizing cost-benefit analysis to guide prosecutorial discretion. ${ }^{166}$ Moreover, as discussed above, a careful analysis of costs and benefits will not only help ensure that prosecutors consider the full implications of their decisions; it may also counter the same cognitive biases that can distort legislative decisions. ${ }^{167}$

b. Perfecting Judicial Decisionmaking. — Like prosecutors, judges play an important role in determining the price of crime. ${ }^{168}$ While the ascendance of plea and charge bargaining and, until recently, the dominance of mandatory sentencing guidelines helped to shift the locus of power from judges to prosecutors, ${ }^{169}$ judges still play a critical role in deciding the price that a guilty defendant ultimately pays for his or her crime. As a result, just as legislators will want to consider the dynamic relationship between first- and second-order criminal markets as they calibrate the statutory penalties for each crime, so too will judges want to consider how their sentencing decisions affect other criminal markets. This does not necessarily suggest that a judge should sentence a defendant charged with a second-order crime more leniently. Rather, judges, like legislators, may need to coordinate their sentencing philosophies. It is possible that the need to harshly penalize a second-order crime will sometimes suggest a stronger sentence is needed for the first-degree crime as well. Conversely, as judges consider "sending a message" with a severe sentence for a second-order crime, they may want to consider what kind of message they will be sending to related criminal markets.

c. Perfecting the Allocation of Law Enforcement Resources. - In his pioneering article introducing his economic approach to crime, Gary Becker explained that deterrence is a function of both the severity of punishment and the probability of detection. ${ }^{170}$ While Becker's original

165. See, e.g., U.S. Dep't of Justice, U.S. Attorney's Manual § 9-28.1000, available at http://www.justice.gov/usao/eousa/foia_reading_room/usam/title $9 / 28 \mathrm{mcrm}$.htm\#9-

28.1000 (on file with the Columbia Law Review) (last modified Aug. 2008) (permitting U.S. Attorneys to consider collateral costs of prosecuting corporations).

166. See Brown, Cost-Benefit Analysis, supra note 139, at 327 (describing potential for cost-benefit analysis to usefully constrain prosecutorial discretion).

167. See supra Part III.A.2 (discussing benefits of cost-benefit analysis for legislators when creating and modifying criminal law).

168. See Robinson \& Darley, supra note 145, at 997 (“Judges, not legislators, impose sentences, and given the wide sentencing discretion that American judges traditionally have had and continue to have in the vast majority of states, judicial discretion not legislative policy will determine deterrent effectiveness.").

169. See Rachel E. Barkow, Recharging the Jury: The Criminal Jury's Constitutional Role in an Era of Mandatory Sentencing, 152 U. Pa. L. Rev. 33, 95-102 (2003) (describing how plea bargaining and mandatory sentencing guidelines have shifted power into prosecutors' hands).

170. Becker, supra note 5, at 176; see also Chris William Sanchirico, Detection Avoidance, 81 N.Y.U. L. Rev. 1331, 1345 (2006) ("[T] he deterrent force exerted by law is viewed 
work presumed that the probability of detection and the severity of sanctions were largely fungible, ${ }^{171}$ some studies suggest that an increase in the probability of apprehension is likely to have a greater deterrent effect than a similar increase in the size of the penalty. ${ }^{172}$ As a result, decisions affecting the likelihood that a criminal will be detected and apprehended may have a greater deterrent impact than legislative, judicial, and prosecutorial decisions affecting sentencing. ${ }^{173}$ The dynamic relationship between first- and second-order criminal markets is thus at least as relevant to decisions affecting the probability of apprehension as it is to decisions regarding the severity of punishment.

While criminal deterrence (and thus public safety) is largely a function of the probability of apprehension, the probability of apprehension is, in turn, largely a function of the allocation of resources. ${ }^{174}$ As a result, one of the most important criminal justice policy decisions revolves around how to spend scarce law enforcement resources so as to get the most "bang for our buck." ${ }^{175}$ The use of high-tech mapping and information-management systems has been heralded as "the most revolution-

as the conjunction of two factors: the probability that violations are 'detected' (i.e., investigated, uncovered, and successfully prosecuted) and the magnitude of the sanction imposed in the event of detection.").

171. See Miriam H. Baer, Linkage and the Deterrence of Corporate Fraud, 94 Va. L. Rev. 1295, 1302-04 (2008) (summarizing Becker's model). While Becker's analysis treated the probability of detection and the severity of sanctions as fungible, he acknowledged the commonly held view that the probability of detection was likely the stronger variable of the two. See Becker, supra note 5, at 176 (" $[\mathrm{A}]$ common generalization by persons with judicial experience is that a change in the probability has a greater effect on the number of offenses than a change in the punishment ....").

172. See Timothy F. Malloy, Regulation, Compliance and the Firm, 76 Temp. L. Rev. 451, 462 n.34 (2003) (citing studies described in James Q. Wilson \& Richard J. Herrnstein, Crime and Human Nature 397-401 (1985)). One possible explanation is that criminals may substantially discount the disutility of increases in future punishment. See A. Mitchell Polinsky \& Steven Shavell, On the Disutility and Discounting of Imprisonment and the Theory of Deterrence, 28 J. Legal Stud. 1, 2 (1999) (describing impact of discounting on deterrent effect of criminal penalties).

173. See Bruce L. Benson, David W. Rasmussen \& Iljoong Kim, Deterrence and Public Policy: Trade-Offs in the Allocation of Police Resources, 18 Int'l Rev. L. \& Econ. 77, 79 (1998) ("Assume that the police are in the business of producing crime deterrence. By allocating capital and labor to control the various crime types, police influence the level of such crimes.").

174. Ryan Cantrell, Note, Finding Nemo . . . and Eating Him: The Failure of the United Nations to Force Internalization of the Negative Social Costs That Result from Overfishing, 5 Wash. U. Global Stud. L. Rev. 381, 395 (2006) ("The probability of apprehension is a function of the resources devoted to detecting the crime ...."); see also M. Todd Henderson, Justin Wolfers \& Eric Zitzewitz, Predicting Crime, 52 Ariz. L. Rev. 15, 16 (2010) ("Public safety is the most important metric for elected officials (especially at the local level) and allocating scarce crime-fighting resources efficiently is an essential element of achieving public safety.").

175. Daniel G. Moriarty, Extending the Defense of Renunciation, 62 Temp. L. Rev. 1, 5 (1989) ("[I]n justice as in national defense, we should get the most 'bang for our buck.'”). 
ary public-sector achievement of the last quarter-century." 176 In addition to improving accountability, "data-driven policing" is intently focused on helping law enforcement efficiently allocate crime-fighting resources. ${ }^{177}$ Compstat, the pioneering data-mapping system implemented in New York City in 1994 and replicated in a number of U.S. cities over the last decade, has been praised for enabling the rapid redeployment of police resources based upon a rise in a particular type of crime or the recognition that a particular area is experiencing increased criminal activity. ${ }^{178}$

Given the amount of money and attention devoted to optimizing the allocation of law enforcement resources, surprisingly little attention has been paid to the impact that allocation decisions have on related criminal markets. If legislators and law enforcement officials want to maximize the impact of their limited resources, they should consider whether the allocation of resources to fight one crime might help to improve the market for a related crime. As discussed above, the criminalization of fake drugs can improve the market for genuine illegal drugs. ${ }^{179}$ An increased allocation of police officers to seek out and arrest fake-drug dealers can similarly improve the genuine drug market. Just as increased penalties for selling fake drugs increase users' confidence that they are purchasing "quality product," the allocation of departmental resources to fighting fake drugs will reduce the costs associated with seeking out known dealers and lower the risk premium that users demand from dealers. ${ }^{180}$ At a minimum, the relationship between criminal markets suggests that law enforcement initiatives that seek to broadly reduce individuals' incentives to engage in crime are likely to have a greater social impact than programs that are targeted against a specific criminal activity. Perhaps more importantly, the relationship between first- and secondorder criminal markets suggests that resources employed to increase arrest rates in a particular criminal market may provide less of a public safety benefit than might initially be presumed. An accurate assessment of the true benefit of allocating resources to increasing arrest rates may ultimately suggest that policymakers should reevaluate the relative merit

176. Heather Mac Donald, Compstat and Its Enemies, City J. (Feb. 17, 2010), http:// www.city-journal.org $/ 2010 /$ eon021 $7 \mathrm{hm}$.html (on file with the Columbia Law Review).

177. See id. ("One of Compstat's most powerful accomplishments was to yoke crime data and analysis intimately to deployment decisions."); see also Henderson et al., supra note 174, at 29 (describing police departments' use of crime-mapping technology to help allocate resources).

178. See generally James J. Willis, Stephen D. Mastrofski \& David Weisburd, Making Sense of Compstat: A Theory-Based Analysis of Organizational Change in Three Police Departments, 41 Law \& Soc'y Rev. 147 (2007) (describing and assessing Compstat).

179. See supra Part II.B (discussing how criminalization of second-order crimes perfects first-order criminal markets).

180. Which, in this case, would take the form of a "risk discount." 
of alternative crime prevention measures that may, ultimately, provide a greater public safety "bang for the buck." 181

4. Perfecting the Policy Debate. - Even if one is skeptical of lawmakers' and other criminal justice actors' ability to deter crime by manipulating criminal laws and penalties, ${ }^{182}$ the relationship between related criminal markets is still relevant to current debates over criminal justice policy. The impact of second-order crimes on first-order criminal markets suggests a level of complexity that has been missing in the public dialogue over criminal law. ${ }^{183}$ At a minimum, the interconnected nature of criminal markets indicates that lawmakers' perpetual solution-to ratchet up punishment and criminalize antisocial activity many times over ${ }^{184}$-may appeal to the public's desire for simple and straightforward solutions but may do little to promote public safety. Perhaps the recognition that further criminalization can promote crime will lead to a more nuanced discussion about the ways in which society can best deter antisocial behavior.

\section{B. Perfecting Our Understanding of (Over)criminalization}

The potential for second-order crimes to perfect first-order criminal markets may provide some valuable insight into the overcriminalization crisis that has been a focus of legal scholars for the last forty years. ${ }^{185}$ Criminal law has been described as a "one-way ratchet," ${ }^{" 186}$ constantly expanding the scope of criminal liability and perpetually increasing the penalties associated with each crime. ${ }^{187}$ As discussed above, various theo-

181. See Brandon C. Welsh \& David P. Farrington, Monetary Costs and Benefits of Crime Prevention Programs, 27 Crime \& Just. 305, 345-46 (2000) (describing six categories of community crime prevention programs ranging from strategies fostering greater youth socialization to order maintenance policies targeting physical and personal disorder and petty crimes).

182. See Robinson \& Darley, supra note 145, at 951 (describing "growing evidence to suggest skepticism about the criminal law's deterrent effect").

183. See id. at 952 ("The deterrent process involves complex interactions, like substitution effects, that make deterrent predictions enormously difficult.").

184. See Stuntz, supra note 8, at 509 (describing criminal law as "one-way ratchet that makes an ever larger slice of the population felons, and that turns real felons into felons several times over").

185. See id. at 507 (" $[\mathrm{C}]$ riminal law's breadth is old news. It has long been a source of academic complaint; indeed, it has long been the starting point for virtually all the scholarship in this field ...."). For a seminal work published in 1967 explaining the overcriminalization crisis, see Kadish, supra note 134.

186. Stuntz, supra note 8, at 509. But see Darryl K. Brown, Democracy and Decriminalization, 86 Tex. L. Rev. 223, 225 (2007) [hereinafter Brown, Democracy and Decriminalization] (challenging notion that criminal codes are constantly expanding and suggesting some areas of criminal law have, in fact, contracted over time).

187. See, e.g., Beale, Non-Legal Factors, supra note 8, at 51-64 (describing psychological framework for expansion of criminal law). 
ries have been offered to explain this unremitting expansion. ${ }^{188}$ Some scholars blame institutional interests that encourage prosecutors and legislators to push for broad criminal liability. ${ }^{189}$ Others have pointed to a legislative process that exaggerates the temporary passions of the electorate ${ }^{190}$ The rising influence of media images of crime has also been blamed for contributing to increased efforts to expand the criminal code. Finally, some academics have suggested that cognitive psychology can explain the public's, and thus elected officials', penchant for punitive and expansive approaches to fighting crime. ${ }^{191}$ Ultimately, the explosive growth of the criminal code is likely due to some combination of the many explanations offered by scholars.

The relationship between first- and second-order criminal markets should not wholly supplant other theories that purport to explain the expansion of the criminal law. Indeed, one of the chief aspects of the overcriminalization phenomenon is the dramatic growth of regulatory crimes ${ }^{192}$ - a likely unrelated aspect of the expansion of the criminal code. However, the perfection of criminal markets suggests a "multiplier effect" that magnifies the impact of those factors that scholars argue explain the dramatic expansion of the criminal code. Media stories detailing the horrific and dangerous conditions that surround human smuggling ${ }^{193}$ were likely the catalyst for Congress's decision to enhance the penalties for alien smugglers who injure or kill their human cargo. ${ }^{194}$ However, if the effect of such laws is to increase other criminal activity, they may instigate further rounds of criminalization and penalization as the legislature seeks to undo the effects of second-order criminalization on related criminal markets. As a result, the relationship between firstand second-order crimes may help explain why seemingly weak influences may in fact have a substantial impact on both the breadth and depth of the criminal law. ${ }^{195}$

The idea that first-order crimes create the opportunity for secondorder criminal markets to emerge offers a partial explanation for the in-

188. See supra notes 151-156 (discussing psychological and cognitive forces affecting expansion of criminal codes).

189. Stuntz, supra note 8 , at 510 .

190. Brown, Democracy and Decriminalization, supra note 186, at 224.

191. Beale, Non-Legal Factors, supra note 8, at 52-53.

192. See Sara Sun Beale, The Many Faces of Overcriminalization: From Morals and Mattress Tags to Overfederalization, 54 Am. U. L. Rev. 747, 748, 781 (2005) (distinguishing growth in regulatory crimes-"mattress tag" offenses-from increase in morals offenses).

193. See, e.g., Verhovek, supra note 51; see also supra notes 50-53 and accompanying text (describing deadly incidents of human smuggling).

194. See supra notes 55-56 and accompanying text (discussing enactment of Violent Crime Control and Law Enforcement Act of 1994).

195. See Stuntz, supra note 8, at 512 ("Criminal law is both broad and deep: a great deal of conduct is criminalized, and of that conduct, a large proportion is criminalized many times over."). 
crease in the number of crimes on the books. If the politics of crime push legislatures to expand the criminal code, each expansion plants the seeds for new antisocial activity to be criminalized. Moreover, if the subsequent criminalization of second-order crimes offsets some of the disincentives to commit the first-order crime, then it is not surprising that the legislature's response would be either to enhance the penalties for the first-order crime or to attack the first-order problem with a second wave of criminalization. The perfection of criminal markets thus helps to explain not only the expansion of the criminal code but also why legislatures see fit to return to the same antisocial conduct and criminalize it "many times over." 196

\section{Perfecting Criminal Norms}

Criminal law does not govern conduct solely by increasing the penalties for engaging in antisocial activities; it also has the capacity to promote social norms of behavior. ${ }^{197}$ In this regard, the law does not simply extract a price for undesirable conduct; it also regulates the social meaning of such activity. ${ }^{198}$ This expressive function of criminal law is considered by many to be a critical (and cost-effective) aspect of the law's ability to deter harmful behavior. ${ }^{199}$ Yet this expressive function can, itself, have hidden costs. ${ }^{200}$ Society largely benefits from the prevailing norm that criminalization imbues an activity with negative moral value. ${ }^{201}$ However, the corollary to that norm-that policies which facilitate an activity convey a message that the activity is morally acceptable-may not always pro-

\section{Id.}

197. Dau-Schmidt, supra note 28 , at 2 (" $[1]$ n addition to creating disincentives for criminal activity, criminal punishment is intended to promote various social norms of individual behavior by shaping the preferences of criminals and the population at large."); see also Dan M. Kahan, Social Influence, Social Meaning, and Deterrence, 83 Va. L. Rev. 349,351 (1997) ("The decisions of individuals to commit crimes are influenced by their perception of others' beliefs and intentions; the law shapes information about what those beliefs and intentions are."); Cass R. Sunstein, Social Norms and Social Roles, 96 Colum. L. Rev. 903, 964 (1996) (explaining expressive function of laws "to constitute and to affect social meanings, social norms, and social roles").

198. Kahan, supra note 197 , at 351 .

199. See, e.g., id. ("Given the power of social influence, laws that shape individuals' perceptions of each others' beliefs and intentions, for example, may often turn out to be the most cost-effective means of deterring crime."); Stuntz, supra note 8, at 520 ("The past few years have seen a growing interest in the expressive potential of criminal law-the use of the criminal justice system not primarily to make and carry out threats, but to send signals. [According to some] this signal-sending is the most important thing criminal law does." (footnote omitted)).

200. See generally Eric A. Posner, Law, Economics, and Inefficient Norms, 144 U. Pa. L. Rev. 1697 (1996) (arguing that, under variety of plausible conditions, social norms may reduce social welfare).

201. See Kahan, supra note 197, at 362 ("Economists speak of criminal law as a mechanism for pricing misconduct, but ordinary citizens think of it as a convention for morally condemning it."). 
mote social welfare. Consider the opposition to harm-reduction programs that allow intravenous drug users to exchange dirty needles for sterile ones. Critics of needle-exchange programs typically argue that, by facilitating the safe use of intravenous needles, exchange programs implicitly condone drug use, and thus promote an activity that is both harmful and illegal. ${ }^{202}$ Importantly, while this argument is ultimately consequentialist, focusing on the overall welfare loss resulting from increased drug use, it also relies on equating facilitation with condonation. This "facilitation norm" is what makes harm-reduction strategies appear undesirable. ${ }^{203}$

Were needle-exchange programs the sole casualty of the facilitation norm, one might be tempted to simply accept the elimination of one seemingly viable strategy for fighting the spread of communicable diseases as a necessary cost of keeping the social meaning of criminalization unambiguous. However, the facilitation norm may foreclose other interesting policy interventions that might improve social welfare despite supporting criminal activity. Imagine providing mediation services to resolve gang turf disputes, helping sex workers obtain documentation that indicates regular HIV testing, or free lab testing for illegal narcotics to ensure purity. ${ }^{204}$ Consider some of the benefits of allowing individuals who engage in criminal activity to use the legal system to resolve their "business" disputes, so that they don't have to resort to violent self-help measures. There are excellent reasons not to provide such services. The inability to use the legal system to resolve disputes is an important economic cost that may make criminal activity less attractive to profit-seeking actors. ${ }^{205}$

202. See Salbu, supra note 133, at 129 ("Some will receive this signal as government condonation or countenance-if drug injection is seriously forbidden, why would the government be giving people implements for the express and admitted purpose of injecting drugs?"); David J. Merrill, Comment, Compassion for Drug Addicts or GovernmentSanctioned Drug Use?: An Overview of the Needle Exchange Controversy, 23 Pepp. L. Rev. 939, 941 (1996) ("[P] robably the most significant problem for the opponents of needle exchange programs[] is a fear that it condones, if not promotes, drug abuse.").

203. An alternative argument is that the risks associated with dirty needles are an important disincentive to engaging in intravenous drug use. To the extent that one believes that the dangers associated with dirty needles deter drug use, one might oppose needleexchange programs regardless of their normative impact.

204. The nonprofit DanceSafe currently sponsors a service that allows individuals to anonymously submit samples of "club drugs" (particularly the drug ecstasy) for free lab testing. EcstasyData.org, http://www.ecstacydata.org (on file with the Columbia Law Review) (last visited Oct. 21, 2012); see also About DanceSafe, DanceSafe.org, http:// www.dancesafe.org/about-dancesafe (on file with the Columbia Law Review) (last visited Oct. 21, 2012) (describing DanceSafe as "a nonprofit, harm reduction organization promoting health and safety within the rave and nightclub community"). The ingredients and the physical description of the drugs are then posted on the service's website. On DanceSafe's efforts to improve drug safety, see Robert J. MacCoun, Testing Drugs Versus Testing for Drug Use: Private Risk Management in the Shadow of Criminal Law, 56 DePaul L. Rev. 507, 524-25, 529-36 (2007).

205. See Reuter, Disorganized Crime, supra note 85, at 109-31 (describing economic costs associated with running illegal businesses). 
However, to the extent that such policies are unacceptable simply because they suggest that society condones the criminalized activity, the facilitation norm may be foreclosing valuable opportunities to improve social welfare.

Scholars have long recognized the tension between the expressive function of criminal law and efforts to improve social welfare by reducing some of the collateral costs of committing crimes. ${ }^{206}$ It is difficult to simultaneously facilitate and condemn an activity. However, the perfection of criminal markets suggests that there is less of a difference between harm reduction strategies and criminalization than many people might assume. Just as the distribution of clean needles makes it cheaper and easier to use illegal drugs, so too does the criminalization of fake drugs make it cheaper and easier to sell real drugs. If the criminalization of the second-order crime does not signal social approval of the first-order criminal market, then harm-reduction policies similarly need not be regarded as sanctioning bad behavior.

Focusing on the ways in which the criminalization of one behavior can facilitate other criminal activity need not undermine the expressive value of criminalizing conduct. The fact that an effort to reduce the harm caused by criminal conduct unintentionally boosts related criminal markets need not dilute the law's moral message. However, it does suggest that alternative policy efforts to reduce harm should similarly be interpreted as not condoning the unlawful activity. If society were to recognize the ways in which criminalization facilitates other criminal activity, creative harm-reduction strategies might come to entail fewer normative costs.

The benefits of destigmatizing harm-reduction strategies are not limited to the drug context. At a time when the Uruguayan Penal Code criminalized abortion, ${ }^{207}$ the government passed a law authorizing physicians to counsel women on the various methods of obtaining the safest illegal abortion. ${ }^{208}$ This policy was lauded for saving lives, but faced criticism for delivering a mixed message as to the morality of obtaining abor-

206. See MacCoun, supra note 204, at 538 ("The expressive and crime-controlling functions of criminal law are often in tension with other social goals, including distributive justice, restorative justice, and risk regulation.").

207. Código Penal [Criminal Code] art. 325 (Ediciones "Del Foro," 2005); see Joanna N. Erdman, Access to Information on Safe Abortion: A Harm Reduction and Human Rights Approach, 34 Harv. J.L. \& Gender 413, 420 (2011) (discussing Uruguay's abortion law). The Uruguayan government has recently decriminalized first-trimester abortion. See Simon Romero, Uruguay's Senate Approves Bill Allowing First-Trimester Abortions for Any Reason, N.Y. Times, Oct. 16, 2012, at A6.

208. Law No. 18426, art. 4, Dec. 1, 2008, available at http://www.parlamento.gub.uy/ leyes/AccesoTextoLey.asp?Ley=18426 (on file with the Columbia Law Review); see also Erdman, supra note 207, at 413-15, 420-21 (describing "Uruguay Model" permitting doctors to provide information about abortion, characterized "as a harm reduction initiative to reduce abortion-related mortality and morbidity"). 
tions. ${ }^{209}$ One benefit of highlighting criminalization's capacity to facilitate crime is that, to the extent that the facilitation norm is weakened, such harm-reduction policies will entail fewer normative costs. As discussed above, the increased penalties for illegal abortions that result in the death of the patient may improve the market for safe illegal abortions. ${ }^{210}$

Perhaps recognizing that criminalization of dangerous abortions improves the first-order illegal abortion market might lessen the criticism of alternative harm-reduction strategies like the Uruguay Model by reducing the degree to which they are seen as condoning illegal abortion. With recognition that criminalization and harm-reduction strategies have similar impacts on criminal markets, it may be possible to obtain the lifesaving benefits of some harm-reduction strategies without paying the cost of sending an ambiguous moral message about the underlying crime.

\section{CONCLUSION}

The fact that the criminalization of one activity may actually improve related criminal markets has profound implications for criminal justice policy and our normative understanding of criminal law. It is highly unlikely that policymakers will ever be able to fashion an optimal scheme of crimes and punishments that maximizes the law's deterrent effect. However, the recognition that second-order crimes can perfect first-order criminal markets may encourage lawmakers to more fully evaluate the costs and benefits of using the criminal law to resolve social problems. Moreover, a deeper understanding of the impact that such crimes have on related criminal markets may improve lawmakers' accuracy as they seek to calibrate criminal penalties in a way that more fully promotes public welfare. At a minimum, recognizing criminal law's capacity to improve criminal markets should improve the public discourse about crime and raise some skepticism about simplistic "tough on crime" solutions to complex social concerns.

Finally, acknowledging the degree to which criminal laws facilitate antisocial activity can also promote a normative shift in our evaluation of harm-reduction policies that reduce the social and personal costs of committing crimes. Rather than undermine the moral authority of the criminal law, highlighting the degree to which such laws facilitate crimi-

209. Some prochoice advocates see this ambiguity as a positive step toward changing social attitudes about abortion. See Erdman, supra note 207, at 414-15 (discussing "conceptual links between harm reduction and [reproductive] rights"). To the extent that highlighting criminalization's capacity to facilitate crime weakens the facilitation norm, it is possible that harm-reduction strategies will be less likely to change social attitudes about the underlying criminal activity.

210. See supra text accompanying notes 120-129 (explaining how increased penalties increase confidence in safety of illegal procedures). 
nal activity could destigmatize policies that may be useful alternatives to criminalization. 